\title{
Assessment of Long and Short Run Relationship Amongst Macroeconomic Variables and Economic Growth of Nepal
}

\author{
Shikha Pokhrel \\ Research Assistant of Institute for Strategic and Socio-Economic Research (ISSR) \\ Email: shikha.ks.141@gmail.com \\ Chakra Bahadur Khadka, PhD \\ Lecturer of Economics, Patan Multiple Campus; Tribhuvan University, Nepal. \\ Email: chakra.khadka@pmc.tu.edu.np
}

\begin{abstract}
This paper examines the long and short run relationship among selected macroeconomic variables and economic growth of Nepal. The objective of the research is to examine empirically the long and short run relationship among macroeconomic variables; gross fixed capital formation, human capital, government expenditure, foreign aid, and trade openness on economic growth of Nepal. The study period spanned from 1975 to 2016. The data has the annual frequency. The time series properties of the data were, first, analyzed using the Augmented Dickey-Fuller (ADF) test and then Auto-Regressive Distributive Lag (ARDL) approach to cointegration is employed to assess the direction of impact and long-run relationships between the variables. Besides these, other diagnostic tests are also conducted. The ARDL bound test analysis depicts the presence of cointegration relationship between real GDP and employed macroeconomic determinants. The negative and significant error correction coefficient further provides substantial evidence that there is long-run association among real gross domestic product and selected macroeconomic variables. The ARDL model shows that Gross fixed capital formation and government expenditure have a significant positive relationship on economic growth in the long run while trade openness has a significant negative relationship on economic growth in the long run. Thus, the findings suggest that GFCF and GE are the major macro determinants to robust the economic growth of Nepal. In order to achieve the desired rate of economic growth it is suggested that there should be a continuous investment in gross fixed capital formation including plants, machinery, raw materials, industrial buildings and technology (research and development). It is also suggested that structural changes should be made in school institutions with the provision of providing quality education with cognitive skills and added resources through quality and skilled teachers. Nepal must have more effective trade openness, particularly by productively controlling import of consumption goods, and by introducing import substitution policies, in boosting their economic growth through international trade.
\end{abstract}

Key words: long-run, short-run, macroeconomic variables, Augmented Dickey-Fuller, ARDL.

JEL Code: C01, C22, E01. 


\section{INTRODUCTION}

The study into the factors that hinder economic growth has been one of the central tenets between theoretical and empirical growth researchers, but little consensus has been reached to date. There are many factors which contribute simultaneously to maintain the sustainable economic growth of a nation. Therefore, the measurement of economic growth of a particular country is complex as so many determinants of growth are contributed simultaneously to gross domestic products (GDP). Economic growth refers to an ability of an economy to increase its productive capacity through which it becomes more capable of producing additional units of goods and services, compared to the previous period. Sustainable economic growth is a major goal of every country in the world as it measures the country's overall economic development. It brings a better standard of living for the community (Suliman \& Osman, 1994).

The Neo-classical growth theorists and Endogenous growth theorists believe that an increase in the accumulation of physical capital and human capital can improve economic growth. The actual investment proved to be the major contributing factor towards economic development and technological progress was exogenously determined in the Neo-classical growth models, Solow (1956), Romer (1987), Lucas (1988) and Barro (1991). It is claimed that even a little robust growth rate can be sustainable over a long period of time only when a country is capable of maintaining capital formation at a sizeable proportion of GDP. Economic theories reveal that capital formation plays crucial roles in economic growth (Beddies, 1999 \& Ghura, 1997).

But since the mid-1980s a wave of new growth theories focus on increasing returns not only in physical but also in human capital and claim that the main engine of economic growth is the accumulation of human capital and the main source of differences in living standards among nations are differences in education and level of skills (Amjad, 2005). Education is generally considered as a powerful tool in reducing poverty, enhancing economic growth, empowering people, improving earnings, promoting a flexiblehealthy environment and creating a competitive economy. The significance and direct role of education cannot be ignored for sustainable development. Education and human capital are essential ingredients for economic growth. Poverty and education are expected to be inversely correlated. Knowledge and skills are imparted through education (Tilak, 1994).

On the other hand, the relationship between trade openness and economic growth has been one of the most extensively examined in the development literature. It has been shown that in the long run, trade openness can potentially enhance economic growth by providing access to goods and services, achieving efficiency in the allocation of resources and improving total factor productivity through technology diffusion and 
knowledge dissemination (Barro \& Sala-i-Martin, 1997; Rivera-Batiz \& Romer, 1991). Grossman and Helpman (1991) show that trade openness improves the transfer of new technologies, facilitating technological progress and productivity improvement and that these benefits depend on the degree of economic openness. On the other hand, the opposing view among others Singer (1950), Prebisch (1962) is not yet convinced of the beneficial impact of trade on growth. They claim that trade can be harmful to less developed countries since their structural characteristics tend to reverse the terms of trade against them. Furthermore, empirical papers (Levine et al. 1992, Harrison et al. 1999) have questioned the view that openness could affect output growth.

In developing nations, the main role of foreign aid in stimulating economic growth is to supplement domestic sources of finance such as savings, thus increasing the amount of investment and capital stock. Three gaps were identified as constraints to growth, which are needed to be filled by foreign aid to enable investment. The three gaps are; Savings gap, Foreign Exchange gap and Fiscal gap. Previous empirical studies on foreign aid and economic growth generate mixed results. Papanek (1973), Gupta and Islam (1983), Hansen and Tarp (2000) and Karras (2006), find evidence for positive impact of foreign aid on growth; Burnside and Dollar (2000) and Brautigam and Knack (2004) find evidence for negative impact of foreign aid and growth, while Mosley (1980), Boone (1996), and Jensen and Paldam (2003) find evidence to suggest that aid has no impact on growth. Adolph Wagner was the first to recognize a positive correlation between government expenditure and economic growth. While some researchers conclude that the effect of government expenditure on economic growth is negative and insignificant (Akpan, 2005) and (Romer, 1990), others indicate that the effect is positive and significant (Korman \& Bratimaserene, 2007) and (Gregorious \& Ghosh, 2007).

Healthy, efficient and competitive macroeconomic environment is vital in enhancing and maintaining the overall stability of an economy. Several economists believe that improvement and innovations in macro variables are must for the healthy growth of the economy. However, in the case of Nepal, questions like what are the driving factors of economic growth and how these factors influenced economic growth is still not uncovered. Against this backdrop, an attempt will be made to study the relationship of selected macroeconomic variables on economic growth in the context of Nepal.

Since achieving higher economic growth rate is important to the economy, therefore, the knowledge of the relationship of economic growth with the macroeconomic variables present in its economic environment, is crucial. Despite the fluctuation in foreign aid, FDI, Consumer Price Index (CPI) and the steady growth of the trade deficit, no obvious relationship between those variables and the economic growth can be discerned. 
Without performing the time series analysis, the way that the macroeconomic variables interact with economic growth will remain ambiguous and it will be difficult to predict how recent development in Nepal's macroeconomic variables will affect economic growth. There is a potential for harnessing positive growth in the economy but the main issue is on understanding the factors driving growth which cannot be done effectively before establishing their impact. There is a need to establish how macroeconomic factors like physical capital, human capital, government expenditure, foreign aid and openness to foreign trade can help drive the economic growth of Nepal where real GDP is taken as a proxy for the economic growth. The target of this paper is to examine empirically the long and short run relationship among macroeconomic variables; physical capital, human capital, government expenditure, foreign aid and openness to foreign trade on economic growth of Nepal using an Auto Regressive Distributive Lag (ARDL) Approach.

\section{REVIEW OF LITERATURE}

The study makes a critical review of the relationship of each of the macroeconomic variables with economic growth. This chapter consists of relevant and existing literature on economic growth both in the context of developed and developing countries to date that attempts to focus on the key determinants of economic growth and the relationship between macroeconomic variables and economic growth. A Matrix of literature review is presented in Table 1.

Table 1: Literature Review Matrix

\begin{tabular}{|l|l|l|l|l|}
\hline Author & Objectives & Variables & Methodology & Results \\
\hline Pritchett (2001) & $\begin{array}{l}\text { Examine the relationship } \\
\text { between education } \\
\text { capital and economic } \\
\text { growth. }\end{array}$ & $\begin{array}{l}\text { GDP per worker } \\
\text { and education } \\
\text { capital }\end{array}$ & $\begin{array}{l}\text { Regression } \\
\text { Analysis }\end{array}$ & $\begin{array}{l}\text { The impact } \\
\text { of education } \\
\text { capital on } \\
\text { the growth } \\
\text { of GDPN per } \\
\text { worker is } \\
\text { negative and } \\
\text { significant. }\end{array}$ \\
\hline Mallik (2008) & $\begin{array}{l}\text { study the link between } \\
\text { foreign aid and economic } \\
\text { growth in the six poorest } \\
\text { African countries. }\end{array}$ & $\begin{array}{l}\text { per-capita real } \\
\text { gross domestic } \\
\text { product, aid, } \\
\text { investment and } \\
\text { openness }\end{array}$ & $\begin{array}{l}\text { ADF, Johansen } \\
\text { Cointegration } \\
\text { test }\end{array}$ & $\begin{array}{l}\text { Foreign aid } \\
\text { has significant } \\
\text { negative impact } \\
\text { on growth in } \\
\text { long run. }\end{array}$ \\
\hline
\end{tabular}

(Table continued) 


\begin{tabular}{|c|c|c|c|c|}
\hline \multicolumn{5}{|c|}{ (Table 1 continued) } \\
\hline $\begin{array}{l}\text { Afzal, Farooq, } \\
\text { Ahmad, } \\
\text { Begum and } \\
\text { Quddus (2010) }\end{array}$ & $\begin{array}{l}\text { Study the relationship } \\
\text { between economic } \\
\text { growth and education } \\
\text { development with } \\
\text { macroeconomic variables }\end{array}$ & $\begin{array}{l}\text { GDP, Physical } \\
\text { Capital, Inflation } \\
\text { and School } \\
\text { Enrollment. }\end{array}$ & $\begin{array}{l}\text { ADF test and } \\
\text { ARDL test }\end{array}$ & $\begin{array}{l}\text { The direct } \\
\text { relationship } \\
\text { between school } \\
\text { enrollment and } \\
\text { physical capital } \\
\text { and economic } \\
\text { growth. }\end{array}$ \\
\hline Vlastou (2010) & $\begin{array}{l}\text { Investigate the } \\
\text { relationship between } \\
\text { openness and growth for } \\
\text { a sample of } 34 \text { African } \\
\text { countries over the period } \\
\text { 1960-2003. }\end{array}$ & $\begin{array}{l}\text { Share of } \\
\text { investment, } \\
\text { Labor Force, GE, } \\
\text { Trade openness, } \\
\text { Technology }\end{array}$ & $\begin{array}{l}\text { Panel unit root } \\
\text { test, panel } \\
\text { cointegration } \\
\text { test, panel } \\
\text { causality test }\end{array}$ & $\begin{array}{l}\text { Negative and } \\
\text { significant } \\
\text { impact of } \\
\text { openness on } \\
\text { output growth } \\
\text { and causality } \\
\text { runs from } \\
\text { openness to } \\
\text { growth only. }\end{array}$ \\
\hline $\begin{array}{l}\text { Ullah and Rauf } \\
\text { (2013) }\end{array}$ & $\begin{array}{l}\text { Analyze the impact of } \\
\text { macroeconomic variables } \\
\text { on economic growth in } \\
\text { case of some selected } \\
\text { countries. }\end{array}$ & $\begin{array}{l}\text { GDP, FDI, } \\
\text { Exports, Saving, } \\
\text { Labor Force, Tax } \\
\text { Revenue } \\
(1990-2010)\end{array}$ & $\begin{array}{l}\text { Panel data } \\
\text { analysis, } \\
\text { Common } \\
\text { effect model, } \\
\text { and Random } \\
\text { effect model }\end{array}$ & $\begin{array}{l}\text { Growth is } \\
\text { positively } \\
\text { affected by } \\
\text { FDI \& Savings, } \\
\text { negatively } \\
\text { affected by } \\
\text { Exports and no } \\
\text { impact of the } \\
\text { labor force and } \\
\text { tax revenue } \\
\text { on economic } \\
\text { growth. }\end{array}$ \\
\hline $\begin{array}{l}\text { Antwi, Mills, } \\
\text { and Zhao } \\
(2013)\end{array}$ & $\begin{array}{l}\text { Study the impact of } \\
\text { macroeconomic factors } \\
\text { on economic growth in } \\
\text { Ghana. }\end{array}$ & $\begin{array}{l}\text { GDP per capita, } \\
\text { physical capital } \\
\text { (k), labor force } \\
\text { (LF), FDI, GE, } \\
\text { INF, AID. } \\
(1980-2010)\end{array}$ & $\begin{array}{l}\text { ADF, Johansen } \\
\text { co-integration, } \\
\text { ECM }\end{array}$ & $\begin{array}{l}\text { INF, K, LF } \\
\text { have positive } \\
\text { relationship } \\
\text { whereas FDI, } \\
\text { GE and AID } \\
\text { have a negative } \\
\text { relationship } \\
\text { with economic } \\
\text { growth. }\end{array}$ \\
\hline $\begin{array}{l}\text { Edoumiekumo } \\
\text { and Opukri } \\
\text { (2013) }\end{array}$ & $\begin{array}{l}\text { Study the contribution } \\
\text { of international trade } \\
\text { to economic growth in } \\
\text { Nigeria. }\end{array}$ & $\begin{array}{l}\text { Export (EXPO), } \\
\text { Imports (IMPO), } \\
\text { RGDP } \\
(1981-2008)\end{array}$ & $\begin{array}{l}\text { ADF test, } \\
\text { Johansen co- } \\
\text { integration } \\
\text { test, Granger } \\
\text { Causality test }\end{array}$ & $\begin{array}{l}\text { A positive long- } \\
\text { run relationship } \\
\text { exists between } \\
\text { RGDP, EXPO, } \\
\text { and IMPO. } \\
\text { RGDP Granger } \\
\text { cause EXPO } \\
\text { and Imports } \\
\text { Granger cause } \\
\text { RGDP and } \\
\text { EXPO. }\end{array}$ \\
\hline
\end{tabular}

(Table continued) 


\begin{tabular}{|c|c|c|c|c|}
\hline \multicolumn{5}{|c|}{ (Table 1 continued) } \\
\hline $\begin{array}{l}\text { Edoumiekumo } \\
\text { and Opukri } \\
(2013)\end{array}$ & $\begin{array}{l}\text { Analyze the contribution } \\
\text { of international trade } \\
\text { to economic growth in } \\
\text { Nigeria. }\end{array}$ & $\begin{array}{l}\text { Export (EXPO), } \\
\text { Imports (IMPO), } \\
\text { RGDP } \\
(1981-2008)\end{array}$ & $\begin{array}{l}\text { ADF test, } \\
\text { Johansen co- } \\
\text { integration } \\
\text { test, Granger } \\
\text { Causality test }\end{array}$ & $\begin{array}{l}\text { A positive long- } \\
\text { run relationship } \\
\text { exists between } \\
\text { RGDP, EXPO, } \\
\text { and IMPO. } \\
\text { RGDP Granger } \\
\text { cause EXPO } \\
\text { and Imports } \\
\text { Granger cause } \\
\text { RGDP and } \\
\text { EXPO. }\end{array}$ \\
\hline $\begin{array}{l}\text { Biswas and } \\
\text { Saha (2014) }\end{array}$ & $\begin{array}{l}\text { Evaluate the growth } \\
\text { determinants }\end{array}$ & \begin{tabular}{|l|} 
GFCF, INF, \\
Employment \\
(EMP), Money \\
supply (MS), \\
FDI, GE, EXPO \\
(1980-2010)
\end{tabular} & $\begin{array}{l}\text { ADF \& PP } \\
\text { test, Johansen } \\
\text { and Juselius } \\
\text { multivariate } \\
\text { co-integration } \\
\text { test, Granger } \\
\text { test, VEC, IRF. }\end{array}$ & $\begin{array}{l}\text { GFCF, EMP, } \\
\text { EXPO, FDI } \\
\text { \& MS have a } \\
\text { positive effect } \\
\text { on India's GDP } \\
\text { whereas INF } \\
\text { and Fiscal } \\
\text { deficit have a } \\
\text { negative effect } \\
\text { on GDP. }\end{array}$ \\
\hline $\begin{array}{l}\text { Hafeez and } \\
\text { Taha (2015) }\end{array}$ & $\begin{array}{l}\text { Analyze the } \\
\text { macroeconomic variables } \\
\text { that affect the economic } \\
\text { growth of Pakistan. }\end{array}$ & $\begin{array}{l}\text { INF, GE, NEXPO, } \\
\text { Domestic saving } \\
\text { (DS), GDP } \\
(1980-2012)\end{array}$ & $\begin{array}{l}\text { ADF test, } \\
\text { Johansen co- } \\
\text { integration } \\
\text { test, VECM }\end{array}$ & $\begin{array}{l}\text { INF \& GE have } \\
\text { a negative } \\
\text { impact on GDP } \\
\text { growth; DS, \& } \\
\text { NEXPO have a } \\
\text { positive impact } \\
\text { on economic } \\
\text { growth. }\end{array}$ \\
\hline $\begin{array}{l}\text { Mbalawa } \\
(2015)\end{array}$ & $\begin{array}{l}\text { Examine the effect of } \\
\text { macroeconomic variables } \\
\text { on economic growth in } \\
\text { Botswana. }\end{array}$ & $\begin{array}{l}\text { FDI, Trade } \\
\text { openness (TO), } \\
\text { GFCF, INF }\end{array}$ & $\begin{array}{l}\text { VEC, IRF, } \\
\text { ADF, Linear } \\
\text { regression, } \\
\text { Granger } \\
\text { causality. }\end{array}$ & $\begin{array}{l}\text { FDI, GFCF, } \\
\text { INF have a } \\
\text { positive impact } \\
\text { on economic } \\
\text { growth, } \\
\text { Causality } \\
\text { moved from } \\
\text { economic } \\
\text { growth to FDI } \\
\text { and from GFCF } \\
\text { to economic } \\
\text { growth }\end{array}$ \\
\hline $\begin{array}{l}\text { Ismaila and } \\
\text { Imoughele } \\
\text { (2015) }\end{array}$ & $\begin{array}{l}\text { Study the } \\
\text { macroeconomic } \\
\text { determinants of } \\
\text { economic growth in } \\
\text { Nigeria by RGDP. } \\
\end{array}$ & $\begin{array}{l}\text { RGDP, Physical } \\
\text { capital, labor } \\
\text { force, FDI, TO, } \\
\text { INF, GE } \\
(1986-2012) \\
\end{array}$ & $\begin{array}{l}\text { ADF test, } \\
\text { Johansen co- } \\
\text { integration } \\
\text { test, OLS, } \\
\text { ECM. }\end{array}$ & $\begin{array}{l}\text { The existence } \\
\text { of a long-run } \\
\text { relationship } \\
\text { between the } \\
\text { variables. }\end{array}$ \\
\hline
\end{tabular}

(Table continued) 


\begin{tabular}{|c|c|c|c|c|}
\hline \multicolumn{5}{|c|}{ (Table 1 continued) } \\
\hline Sallam (2016) & $\begin{array}{l}\text { Investigate the role } \\
\text { of imports, exports, } \\
\text { GFCF, \& INF in } \\
\text { promoting economic } \\
\text { growth in Egypt. }\end{array}$ & $\begin{array}{l}\text { GFCF, INF, } \\
\text { EXP, IMP, } \\
\text { GDP. } \\
(1970-2013)\end{array}$ & $\begin{array}{l}\text { ADF \& PP test, } \\
\text { ARDL, VECM }\end{array}$ & $\begin{array}{l}\text { Export shows } \\
\text { positive impact } \\
\text { while Imports } \\
\text { \& GFCF show a } \\
\text { negative impact } \\
\text { on economic } \\
\text { growth. }\end{array}$ \\
\hline Keho (2017) & $\begin{array}{l}\text { Examines the impact } \\
\text { of trade openness on } \\
\text { economic growth }\end{array}$ & $\begin{array}{l}\text { GDP, capital } \\
\text { stock, labor, } \\
\text { and trade } \\
\text { openness }\end{array}$ & $\begin{array}{l}\text { ADF test, ARDL } \\
\text { test, Toda } \\
\text { Yamamoto Granger } \\
\text { Causality test }\end{array}$ & $\begin{array}{l}\text { Trade openness } \\
\text { has positive } \\
\text { effects on } \\
\text { economic } \\
\text { growth both in } \\
\text { the short and } \\
\text { long run. } \\
\end{array}$ \\
\hline $\begin{array}{l}\text { Khan, Najir, } \\
\text { Fareed, Najir, } \\
\text { and Faryal } \\
\text { (2017) }\end{array}$ & $\begin{array}{l}\text { Find out the impact of } \\
\text { inflation, investment, } \\
\text { exchange rate \& } \\
\text { net export on the } \\
\text { development of } \\
\text { Pakistan. }\end{array}$ & $\begin{array}{l}\text { GDP, } \\
\text { NEXPO, } \\
\text { INF, } \\
\text { Investment, } \\
\text { Exchange } \\
\text { Rate (EXR) } \\
(1975-2015)\end{array}$ & $\begin{array}{l}\text { Multiple regression } \\
\text { analysis }\end{array}$ & $\begin{array}{l}\text { INF has a } \\
\text { negative impact } \\
\text { on economic } \\
\text { growth while } \\
\text { investment, } \\
\text { EXPO \& EXR } \\
\text { have a positive } \\
\text { impact on } \\
\text { economic } \\
\text { growth. }\end{array}$ \\
\hline
\end{tabular}

Thus, this study differs from other studies on the ground of macroeconomic variables which are in real per worker form, as five major macroeconomic variables (gross fixed capital formation, human capital, government expenditure, foreign aid, and trade openness) were studied and their impact on growth has been analyzed covering their growth trends also.

\section{RESEARCH METHODOLOGY}

There have been divergent views expressed in the sources of economic growth over time. Economists have been trying to understand why and how poor countries become rich and rich countries become richer since the time of Adam Smith in the eighteen centuries. Four main theories have been proposed. They are: (i) Classical Growth Theory, (ii) Keynesian Growth Theory, (iii) Neoclassical Growth Theory and (iv) Endogenous Growth Theory.

\section{Classical Growth Theory}

The first work in economic theory which deals with the issues of economic growth is the work by Adam Smith titled: "Inquiry into the Nature and Cause of the Wealth of Nations" (1776). He explained that the output depends on the amount of input (labor, capital, and land) and the output growth is determined by the population growth, 
increase in investments, land and the total labor productivity growth. The main factor of economic growth was the division of labor, which leads to the output growth, technical progress, and accumulation. According to Smith, the division of labor is limited by the market dimension. If the division of labor increases than the output, then it increases the market dimension and induces further division of labor and as a result brings about further economic growth.

Another factor which stimulates economic growth according to Smith is capital accumulation. It is based on the saving of main capitalists. For that reason, Smith considered income division as one of the most important determinants of rapid economic growth. Smith approved the necessity of state interventions to a market economy. This model can be written as follows:

$\mathrm{Y}=\mathrm{f}(\mathrm{L}, \mathrm{K}, \mathrm{D})$

Where $\mathrm{Y}$ denotes output, $\mathrm{L}$ denotes labor, $\mathrm{K}$ denotes capital and $\mathrm{D}$ represents land, such that output is related to labor, capital and land inputs.

David Ricardo and Thomas Robert Malthus took up Adam Smith's (1776) theory in the first half of the 19th century. They implemented the law of decreasing returns to the theory of economic growth. At the end of the 1920s, the theory of growth was enriched by Ramsey's "intertemporal optimization of households' behavior". The idea was accepted in the 1960s.

\section{Keynesian Growth Theory}

Keynesian growth theory is mainly connected with Harrod (1939) and Domar (1946). These neo-Keynesian economists tried independently to dynamize Keynesian theory. In their scientific work, Harrod (1939) started from the accelerator principle and Domar (1946) started from the multiplication effect. Despite the different approaches, they came to the same conclusion that the rate of growth of output is determined jointly by the national savings ratio and national capital-output ratio. In economic literature, their theory appears as Harrod-Domar Keynesian theory of growth or simply, HarrodDomar growth model (Harrod, 1939; Domar, 1946).

The Harrod-Domar growth model shows through a mathematical equation, the existence of a direct relationship between savings and the rate of economic growth. The model, which attempts to integrate Keynesian analysis with the element of economic growth, assumes that economic growth is a direct result of capital accumulation in the form of savings. In addition, the Harrod-Domar growth model assumes a fixed coefficient production function and constant returns to scale. To illustrate the Harrod- 
Domar growth model, Savings (S) is some proportion (s) of national income (Y) such that

$\mathrm{S}=\mathrm{s} Y$

Investment $(\mathrm{I})$ is defined as the change in capital stock $(\mathrm{K})$ and can be represented by $\Delta \mathrm{K}$ such that:

$\mathrm{I}=\Delta \mathrm{K}$

Total capital stock $(\mathrm{K})$ is directly related to national income $(\mathrm{Y})$ as represented by the capital-output ratio $(\mathrm{k})$ such that:

$\mathrm{K} / \mathrm{Y}=\mathrm{k}$

The capital-output ratio can be written in its marginal value as:

$\Delta \mathrm{K} / \Delta \mathrm{Y}=\mathrm{k}$

This is popularly known as the incremental capital-output ratio. Since the equilibrium saving (S) must equal total investment (I), it follows that:

$\mathrm{s} \mathrm{Y}=\mathrm{k} \Delta \mathrm{Y}$

In a more familiar expression,

$\Delta \mathrm{Y} / \mathrm{Y}=\mathrm{s} / \mathrm{k}$

This equation tells us that that the rate of growth of output is determined jointly by the national savings ratio (s), and the national capital-output ratio (k). It also says that the growth rate of national income will be directly related to the saving ratio and inversely related to capital-output ratio.

TheHarrod-Domar growth model has been used by developmenteconomists to estimate the financing gap of a developing economy. The Post Keynesians (for example, Kaldor, 1955; Pasinetti, 1962; Robinson, 1962) tried to supplement the Harrod-Domar model with the mechanism of establishing equilibrium. Their approach was significantly influenced by the rate of savings which is derived from the division theory. 


\section{Neoclassical Growth Theory}

Being dissatisfied with Harrod-Domar's knife edge (Razor edge) instability in the growth process due to the assumption of fixed capital-output ratio, neoclassical growth model has been put forward. The most known neo-classical models are the Solow (1956) and Swan (1956) model. The model tries to explain the output determination using the reciprocal interaction of capital, labor, and technology. The Solow model implies that if a country's national saving rate rises, growth will temporarily rise above its long-run rate as the economy shifts to its new equilibrium. However, long-run equilibrium growth is independent of the savings rate or the population growth rate. If all countries have access to the same technology, all should have the same steadystate (long-run) growth rate.

Thus, for the neoclassical growth theorist, long-term per capita growth is determined by the capital-labor ratio, human capital accumulation and the pace of technological progress.

$\mathrm{Y}=\mathrm{f}(\mathrm{A}, \mathrm{K}, \mathrm{L})$

Where, $\mathrm{Y}$ is a gross domestic product, $\mathrm{K}$ capital, $\mathrm{L}$ is labor and $\mathrm{A}$ is a constant reflecting the base level of technology. When the optimum level of capital-labor ratio is attained marginal productivity declines as a result of which economic growth retards. This theory does not explain the advancement of technology which is a major driving force for growth. To overcome this backdrop endogenous growth model was proposed.

\section{Endogenous Growth Model}

The endogenous growth theory was developed as a reaction to omissions and deficiencies in the Solow- Swan neoclassical growth model. It is a new theory which explains the long-run growth rate of an economy on the basis of endogenous factors as against exogenous factors of the neoclassical growth theory. The first ideas of new endogenous growth theory appeared in Paul M. Romer's work on the "Increasing Returns and Long-Run Growth" in 1986, Robert E. Lucas' work on the "Mechanics of Economic Development" in 1988 and Paul M. Romer's work on the "Endogenous Technological Change" in 1990. The endogenous growth models emphasize technical progress resulting from the rate of investment, the size of the capital stock, and the stock of human capital.

The development of new endogenous growth theory is linked with explicitly involved research and development ( $R$ and $D)$ and imperfect competition. The conception can be followed in Romer's work in 1987, Grossman and Helpman (1992). Romer took three 
key elements in his model, namely externalities, increasing returns in the production of output and diminishing returns in the production of new knowledge. In his model, new knowledge is the ultimate determinant of long-run growth which is determined by investment in research technology. Lucas assumes that investment in education leads to the production of human capital which is the crucial determinant in the growth process. He makes a distinction between the internal effects of human capital where the individual worker undergoing training becomes more productive and external effects which spillover and increase the productivity of capital and of other workers in the economy. It is an investment in human capital rather than physical capital that have spillover effects that increase the level of technology.

The endogenous growth theory can be expressed in a simple equation:

$\mathrm{Y}=\mathrm{AK}$

Where A can be interpreted as any factor that affects technology and; $\mathrm{K}$ represents both human and physical capital.

\section{SOURCES OF DATA}

The study is based essentially on secondary data which is sourced from various publications and bulleting of the Nepal Rastra Bank (NRB), Ministry of Finance (MOF), Government of Nepal, and Central Bureau of Statistics (CBS). The data on RGDP, GFCF, GE, and TO are extracted from the various issues of NRB, the data on labor force is generated by interpolation and extrapolation of the population census data from population census 2068 of Nepal and the data on students enrollment and deflator are extracted from the Economic survey, FY 2010/11, Statistical Tables Vol.2, Government of Nepal, Ministry of Finance (2011); Economic Survey, FY 2014/15, Government of Nepal, Ministry of Finance (2015) and Economic Survey, FY 2017/18, Government of Nepal, Ministry of Finance (2018, Nepali Version). The procedure for the data collection is relatively simple. The data that are collected with regard to real GDP, gross fixed capital formation, human capital, government expenditure, trade openness and foreign aid covered the period 1975 to 2016 which gives forty-two (42) years of observation which is statistically large to be used for the study.

\section{Specification of Model}

Following Mankiw, Romer, and Weil (1992), the specification of this study begins with an aggregate production function augmented by education_ centric human capital.

$\mathrm{Y}=\mathrm{AK}^{\alpha} \mathrm{HC}^{\beta} \mathrm{L}^{1-\alpha-\beta}$ 
Where, $\mathrm{Y}$ is output, A is level of technology, $\mathrm{k}$ is physical capital, $\mathrm{HC}$ is stock of human capital and $\mathrm{L}$ is labor force. $\alpha$ and $\beta$ are the elasticity of $\mathrm{Y}$ with respect to physical capital and human capital.

This function assumes a constant return to scale (CRS). In order to transform the production function of equation (10) into per worker form dividing both side of equation (10) by 'L' gives:

$\mathrm{Y} / \mathrm{L}=\mathrm{A}(\mathrm{K} / \mathrm{L})^{\alpha}(\mathrm{HC} / \mathrm{L})^{\beta}$

Taking natural logarithm on both sides of equation (11) it gives:

$\ln \mathrm{Y}=\ln \mathrm{A}+\alpha \ln \mathrm{K}+\beta \ln \mathrm{HC}$

Where,

$\mathrm{Y}$ is the level of output, $\alpha$ and $\beta$ are the elasticity of $\mathrm{Y}$ with respect to physical capital and human capital. This equation shows how per capita income depends on physical capital and human capital. The model is of the form:

$\ln R G D P=a_{0}+a_{1} \ln G F C F+a_{2} \ln H C+a_{3} \ln G E+a_{4} \ln T O+a_{5} \ln A I D+U_{t}$

Where, RGDP represents the real gross domestic product; GFCF represents Gross Fixed Capital Formation a proxy measure of physical capital (k); HC represents Education_ Centric Human Capital which is measured as school enrollment from grade 1-10; GE represents Government Expenditure; TO represents Openness to Foreign Trade measured as export + import/gross domestic product; AID represents Foreign Aid; ln represents shorthand of the natural logarithm; $a_{0}$ is a constant, and $a_{1}, a_{2} \ldots a_{5}$ are the partial elasticities (sensitivity) of real GDP with respect to GFCF, HC, GE, AID and TO respectively; $U_{t}$ is the error term assumed to be normally and independently distributed with zero mean and constant variance, which captures all other explanatory variables which influence economic growth but are not captured in the model.

The existing study attempts to investigate the impact of macro-variables on economic growth in Nepal using the newly developed ARDL-Bounds testing approach. Unlike other co-integration techniques, the ARDL does not impose a restrictive assumption that all the variables under study must be integrated of the same order. Secondly, while other co-integration techniques are sensitive to the size of the sample, the ARDL test is suitable even if the sample size is small. 


\section{Unit Root Tests}

Unit root test is employed to test whether the data are stationary in level, first difference or second difference. The stationary test is highly studied phenomenon for the time series variables in the econometrics. The majority of study on time series is based upon the assumption of stationary. To test the time series data for stationarity a common method is applied an Augmented Dickey-Fuller test (ADF) (Dickey \& Fuller 1979; Brooks, 2014) to test for a unit root. A time series with a unit root is said to be non-stationary. There are other common methods for determining the stationary of a variable such as the Phillips-Perron (PP) test (Phillips \& Perron, 1988) and Kwiatkowski-Phillips- Schmidt, and Shin Statics (KPSS) test. The other tests are similar to the ADF test but with a few alternations in order to allow for auto-correlated residuals. However, the tests often provide similar conclusions (Brooks, 2014) and therefore, this study consider the ADF test as sufficient enough for this purpose. According to (Brooks, 2014) stationarity can be defined as a time series with a constant mean, constant variance and constant auto-covariance for each given lag i.e. all are constant over time. Stationarity or nonstationarity of the underlying time series may have a strong influence of the series behavior and properties and has, therefore, become an important concept in the field of statistics (Brooks, 2014).

A famous fallacy of the usage of non-stationary data in statistics is a concept called spurious regression which refers to the phenomenon of receiving a relationship in a regression between two variables despite that they are independent. However, if the times series are non-stationary it is possible that the regression may provide a high $\mathrm{R}^{2}$ even though the variables have no connection. Thereby if one conduct a regression on non-stationary data one may obtain good looking but useless results (Brooks, 2014). A non-stationary time series $\mathrm{Y}_{\mathrm{t}}$ that is stationary in first difference is said to be integrated of order one and is denoted by $\mathrm{I}(1)$. if the series is stationary at level e.g. $\mathrm{Y}_{\mathrm{t}}$ (nondifferenced) it is denoted by I(0) (Brooks, 2014).

The ADF test is a regression analysis based on equation (14) where $\beta$ is a constant, $\mathrm{p}$ the chosen lag, $\mathrm{t}$ is a time trend variable, $\Delta$ denotes the first difference operator, $\varphi$ and $\alpha$ are the coefficients of the regression, $\mathrm{U}_{\mathrm{t}}$ is the error term.

$\Delta \mathrm{Y}_{\mathrm{t}=} \beta+\lambda \mathrm{t}+\varphi \mathrm{Y}_{\mathrm{t}-1}+\sum_{\mathrm{i}=1}^{\mathrm{p}} \alpha_{\mathrm{i}} \Delta \mathrm{y}_{\mathrm{t}-\mathrm{i}}+\mathrm{U}_{\mathrm{t}}$

Practically, the rejection of the null hypothesis of non- stationary in favor of the alternative hypothesis of stationary is better for conducting time series analysis. The rejection of the null hypothesis in favor of the alternative hypothesis implies that $\mathrm{Y}_{\mathrm{t}}$ is stationary and integrated of order zero, that is, $\mathrm{I}(0)$. If the null hypothesis of a unit root 
for the first difference is rejected, then the first difference is stationary and the variable is integrated of order one, that is, I(1) (Johansen, 1988).

\section{ARDL Bound Test Approach to Co-integration}

After knowing that variables of interest are cointegrated of order zero or one the second step is to apply co-integration test. Co-integration is a statistical property of time series variables. The regression analysis of time series has been much benefited from the concept of co-integration by Granger (1981) and Engle and Granger (1987). They showed that using OLS in case of I (1) variables could be dangerous because a non-stationary series violates the basic assumptions of OLS and as such one cannot get the best linear unbiased estimators (BLUE) and also there may exist the spurious or non-sense correlation between non-stationary variables. In the case where the variables are non-stationary at levels but are difference stationary, co-integration methodology allows researchers to test for the presence of long-run equilibrium relationships between economic variables. Two or more time series are co-integrated if they share a common stochastic drift or if the separate economic time series are stationary after differencing or they are integrated of order one, but a linear combination of their levels is stationary, then the series is said to be co-integrated. In other words, two or more I (l) time series are said to be co-integrated if some linear combination of them is stationary.

The Autoregressive Distributed Lag (ARDL) bounds testing approach has been employed in this paper to examine the impact of macroeconomic variables on economic growth in Nepal. The ARDL modeling approach was originally introduced by Pesaran and Shin (1999) and further extended by Pesaran, Shin and Smith (2001) is based on the assumption that time series under investigation are integrated of order zero I (0), or integrated of order one, I (1) or mutually co-integrated. This approach is based on the estimation of an Unrestricted Error Correction Model (UECM) which enjoys several advantages over the conventional type of co-integration techniques such as Engle-Granger (1987), Johansen-Juselius (1990). Some of the advantages are:

It can be applied for co-integration analysis of small sample study (Pesaran, Shin \& Smith, 2001; Narayan \& Smith, 2005). Therefore, conducting bounds testing will be appropriate for the present study.

It can be applied irrespective of whether the regressors are I (0), I (1) or even integrated of the same order or mutually cointegrated. This is well known that the conventionally used cointegration approaches, for example, Engle and Granger (1987), Johansen (1988), Johansen and Juselius (1990), are applicable for nonstationary series with a same order of integration, I (1). 
The short, as well as long-run parameters of the model could be estimated simultaneously. The UECM is likely to have better statistical properties than the twostep Engle-Granger (E-G) method (Narayan \& Smith, 2005) because unlike the E-G method, the UECM does not push the short run dynamics into the residual's terms (Banerjee, Dolado, Galbraith \& Hendry, 1993; Banerjee, Dolado \& Mestre, 1998; Pattichis, 1999). Additionally, this approach allows to derive a dynamic error-correction model from ARDL through simple linear transformation (Banerjee, Dolado, Galbraith \& Hendry, 1993) that integrates the short run-dynamics with long-run equilibrium without losing long-run information and thus allows to draw inference for long-run estimates that is not available in other alternative cointegration procedures (Sezgin \& Yildirim, 2002). Thus, the ARDL approach estimates both the long run and short run relationships simultaneously.

The ARDL method can distinguish between dependent and explanatory variables and eradicate the problems that may arise due to the presence of autocorrelation and endogeneity (Rehman \& Afzal, 2003).

It provides unbiased estimates of the long-run model and valid t-statistics because they avoid the problems that may arise due to serial correlation and endogeneity (Harris \& Sollis, 2003; Odhiambo, 2009).

The ARDL Model applies a general-to-specific modeling framework by taking a sufficient number of lags to capture the data generating process. It estimates $(\mathrm{p}+1) \mathrm{k}$ number of regressions in order to obtain an optimal lag length for each variable, where $\mathrm{p}$ is the maximum lag to be used, and $\mathrm{k}$ is the number of variables in the equation. The model is selected on the basis of different criteria like Schwartz Bayesian Criteria (SBC), Akaike Information Criterion (AIC) and Hannan-Quinn Criterion (HQC). Once the orders of the lags in the ARDL model have been appropriately selected, then the co-integration relationship can be estimated using a simple Ordinary Least Square (OLS) method.

When analyzing possible relationships between two or more variables the researcher often postulates specifications according to e.g. equation (15), where $Y$ is the dependent variable and $\mathrm{X}$ is a vector of independent variables and $\mathrm{f}$ is some function.

$Y=f(X)$

The ARDL model procedure introduced by Pesaran et al. (2001) is a model that tries to capture the relationship in $f(X)$. 
Following the work by Pesaran and Shin (1998) and Pesaran et al. (2001), the ARDL(q,p) model of equation (15) can be specified by equation (16) where $Y_{t}$ is the dependent variable and $X_{t}$ is the independent variable and $q, p$ are the respective lags.

$\Delta Y_{t}=\beta_{0}+C_{0} t+\sum_{i=1}^{q} \tau_{i} \Delta Y_{t-i}+\Sigma_{j=1}^{p} \omega X_{t-j}+\gamma_{1} Y_{t-1}+t$

The coefficient $\beta_{0} C_{0}$ are the drift and trend coefficient respectively and ${ }_{t}$ is the white noise error. The coefficients $\beta_{0}$ and $C_{0}$ for all $\mathrm{j}$ corresponds to the short-run relationship while the $\gamma_{j} ; j=1,2$ corresponds to the long-run relationship.

\section{Lag Length Selection}

Akaike Information Criterion (AIC), the Schwartz Bayesian Criteria (SBC) or Hannan-Quinn Criterion (HQC) can be used in order to choose the lag order. Then the estimation of the model should be carried out based on the number of lags suggested by the information criteria suggested. However, the AIC criterion has been used in this study to select the optimum lag in the ARDL model.

\section{F- bound Test}

To test if the variables have a long-run relationship, the F-test will be performed. If the computed F-statistics is greater than the proper upper bound critical values, the null hypothesis of no co-integration is rejected in favor of co-integration. If the computed F-statistics falls below the lower bound critical values, the null of no cointegration cannot be rejected in which case there is the absence of co-integration. If the computed F-statistic falls within the critical value band (i.e., if it falls within the upper and lower bounds), the result is inconclusive. Under the inconclusive situation, following Kremers, Ericsson and Dolado (1992) and Banerjee, Dolado and Mestre (1998), the error correction term (ECT) will be a useful way of confirming co-integration (Verma, 2007). Of course, the significance of the error correction term should be kept in mind, as it is the useful way of establishing co-integration. Following Pesaran, Shin and Smith (2001) and following the description above and equation (16) the applied ARDL model is given in equation (17).

$$
\begin{aligned}
& \Delta \operatorname{lnRDP}=\mu+\sum_{\mathrm{i}=0}^{\mathrm{m}} \eta_{\mathrm{i}} \Delta \mathrm{InRDP} \mathrm{t}_{\mathrm{t}-\mathrm{i}}+\sum_{\mathrm{i}=0}^{\mathrm{n}} \omega_{\mathrm{i}} \Delta \mathrm{InGFCF}_{\mathrm{t}-\mathrm{i}}+\sum_{\mathrm{i}=0}^{\mathrm{p}} \varphi_{\mathrm{i}} \Delta \mathrm{InHC}_{\mathrm{t}-\mathrm{i}}+\sum_{\mathrm{i}=0}^{\mathrm{q}} \pi_{\mathrm{i}} \Delta \mathrm{InGE}_{\mathrm{t}-\mathrm{i}}+ \\
& \sum_{\mathrm{i}=0}^{\mathrm{r}} \lambda_{\mathrm{i}} \Delta \operatorname{lnAID} \mathrm{It-i}_{\mathrm{i}}+\sum_{\mathrm{i}=0}^{\mathrm{s}} \psi \mathrm{L}_{\mathrm{i}} \Delta \mathrm{InTO}_{\mathrm{t}-\mathrm{i}}+\theta_{1} \operatorname{lnRGDP}_{\mathrm{t}-1}+\theta_{2} \operatorname{lnGCF}_{\mathrm{t}-1}+\theta_{3} \operatorname{lnH}_{\mathrm{t}-1}+\theta_{4} \operatorname{lnGE}_{\mathrm{t}-1}+\theta_{5} \\
& \operatorname{lnFA} A_{t-i}+\theta_{6} \operatorname{lnTO}_{t-1}+\mathrm{Vt} \text {. }
\end{aligned}
$$

Where $\Delta$ denotes first difference operator, $\mu$ is the intercept term, $v$ is the usual white noise and $\mathrm{m}, \mathrm{n}, \mathrm{p}, \mathrm{q}, \mathrm{r}, \mathrm{s}$ is the chosen lag of first-differenced variables. The remaining 
coefficients describe short-run and long-run relationships. The $\theta_{j} ; j=1,2, .6$ correspond to the long-run relationship while the short-run effects are captured by the coefficients for the first difference variables i.e. $\eta_{\mathrm{i}^{\prime}} \omega_{\mathrm{i}^{\prime}} \phi_{\mathrm{i}^{\prime}}, \pi_{\mathrm{i}^{\prime}} \lambda_{\mathrm{i}^{\prime}} \psi_{\mathrm{i}}$.

Equation (17) differs from standard distributed lag models in that it includes a linear combination of the lagged level of all variables, normally referred to as an error correction term (Bahamani-Oskooee \& Ardalani, 2006). The ARDL model given in equation (17) integrates the short-run dynamics with the long run equilibrium without losing any information for the long run.

According to Pesaran and Pesaran (1997), the ARDL approach involves two steps for estimating the long-run relationship. The first step is to examine the existence of a long-run relationship among all variables in the equation's underestimation. And for that we calculate F-statistic through (Wald test) where the null hypothesis that there is no co-integration relationship between the variables model) the absence of a long-run equilibrium relationship: $H_{0}: \theta_{1}=\theta_{2}=\theta_{3}=\theta_{4}=\theta_{5}=0$ (no co-integration). While the alternative hypothesis that there is a co-integration relationship among the variables model: $H_{1}: \theta_{1} \neq \theta_{2} \neq \theta_{3} \neq \theta_{4} \neq \theta_{5} \neq 0$ (co-integration).

After finding a long-run relationship in the first step, the second step of the analysis is processed forward, which is to estimate the coefficients of the long-run relationship and determine their values, followed by the estimation of the short-run elasticity of the variables with the error correction representation of the ARDL model (Tzougas, 2013).

\section{Testing for Short-run Coefficients (Error correction Modeling)}

To define an ECM-term, which is the second step in the ARDL approach a few assumptions have to be made. Given that if the F-bound test produces satisfactory results it is possible to determine the long-run equilibrium relationship without spurious regression as the linear combination of the non-stationary variables are stationary in a simple OLS framework:

$Y_{t}=\beta_{1}+\beta_{2} X_{t}+t$

Even if $Y_{t}$ and $X_{t}$ variables are cointegrated, i.e. there is a long run equilibrium relationship between them, there may be disequilibrium in the short run. Thus, the error term $E C M=Y_{t}-\beta_{1}-\beta_{2} X_{t}$ in the regression equation (18) is called the equilibrium error. This error term can be used to tie the short run behavior of $Y$ to its long run value. The Error correction Models (ECM) was first used by Sargan (1984) and later popularized by Engle and Granger corrects for disequilibrium. 
To capture the convergence of the model towards equilibrium an error correction term is defined by $E C M_{t-1}=Y_{t=1}-\beta_{1}-\beta_{2} X_{t-1}$ where $\beta_{i} s$ are the estimators from equation (18). $\mathrm{ECM}_{\mathrm{t}-1}$ is the residuals from equation (18). Furthermore, if the model is moving towards equilibrium in the long-run the difference between the independent and dependent variables $\left(\mathrm{ECM}_{\mathrm{t}-1}\right)$ cannot increase as that would impose divergence. Hence the difference must decrease. Furthermore as $X_{t^{\prime}} Y_{t}$ and $\beta_{j}$ are all given from the regression in equation (18), $\mathrm{ECM}_{\mathrm{t}-1}$ becomes a new data series. In the final step, the short-run dynamics are estimated by using equation (17) by replacing the lagged variables $X_{t^{\prime}} Y_{t}$, with the error correction term $\mathrm{ECM}_{\mathrm{t}-1}$. In other words, In the ARDL approach to co-integration the lagged error correction term $\left(\mathrm{ECM}_{\mathrm{t}-1}\right)$ is generated out of the long-run coefficients to replace a linear combination of the lagged variables, and the model is re-estimated at the optimum lags selected by using model selection criterion (Bahamani- Oskooee \& Ardalani, 2006). Hence the short- run error correction version of model can be specified as the follows:

$$
\begin{aligned}
& \Delta \mathrm{InRGP}=\mu+\sum_{\mathrm{i}=0}^{\mathrm{m}} \eta_{\mathrm{i}} \Delta \mathrm{InRGDP} \mathrm{t}-\mathrm{i}+\sum_{\mathrm{i}=0}^{\mathrm{n}} \omega_{\mathrm{i}} \Delta \mathrm{InGFCF}_{\mathrm{t}-\mathrm{i}}+\sum_{\mathrm{i}=0}^{\mathrm{p}} \varphi_{\mathrm{i}} \Delta \mathrm{InHC}_{\mathrm{t}-1}+\sum_{\mathrm{i}=0}^{\mathrm{q}} \pi_{\mathrm{i}} \Delta \mathrm{InGE} \mathrm{t}_{\mathrm{t}-\mathrm{i}}+ \\
& \sum_{\mathrm{i}=0}^{\mathrm{r}} \lambda_{\mathrm{i}} \Delta \mathrm{InAID} \mathrm{t}_{\mathrm{t}-\mathrm{i}}+\sum_{\mathrm{i}=0}^{\mathrm{s}} \psi_{\mathrm{i}} \Delta \mathrm{InTO}_{\mathrm{t}-\mathrm{i}}+\gamma \mathrm{ECM}_{\mathrm{t}-1}
\end{aligned}
$$

In equation (19) ECM is the error correction mechanism term obtained as residual from the estimation of the long run co-integrating equation (17); $\eta_{\mathrm{i}^{\prime}} \omega_{\mathrm{i}^{\prime}} \phi_{\mathrm{i}^{\prime}} \pi_{\mathrm{i}^{\prime}} \lambda_{\mathrm{i}}$ and $\psi_{\mathrm{i}}$ are the short run dynamic coefficients of the model's convergence to equilibrium, and $\gamma$ determines the speed of adjustment from short run to long run i.e. towards equilibrium.

The error correction term (ECM) among a set of co-integrated series implies that changes in the response variable are functions of both the levels of disequilibrium in the co-integrating relationship (represented by the ECM) and the changes in other explanatory variables. The ECM coefficient $\gamma$ must be statistically significant and negative in order for the model to converge to equilibrium that is $\gamma$ must be less than zero $(\gamma<0)$. Furthermore, a significant ECM coefficient confirms the existence of a stable long-run relationship and co-integration between the independent and dependent variables. Banerjee, Dolado, and Mestre (1998) note that significant lagged error term with a negative sign is the way to prove that established long-run relationship is stable. The larger the size of the negative coefficient of the error correction term, the greater is the speed of adjustment from short run to long run.

\section{Diagnostic Testing}

The ARDL model tries to find the best linear unbiased estimator (BLUE) and thereby diagnostic tests need to be conducted. As many other research papers such as Tian and Ma (2010); Hasan and Nasir (2008), this study will further validate the results 
and ensure that the results are statistically robust by utilizing tests for stability, serial correlation, heteroscedasticity, and normality in the residuals. If the model contains none of the addressed biases and the model provides satisfactory results, then the results can be used for the analysis.

\section{Regression Specification Error Test}

Ramsey Regression Specification Error Test (RESET) (Ramsey, 1969) for functional form i.e. it tests if non-linear combinations of the fitted values can describe the explanatory variable. If non-linear combinations of the fitted values have power in describing the explanatory variable the model is said to be misspecified and needs adjustments. Thus, it is used to check whether the specified functional form is correct or not. The non-mathematical null and alternative hypotheses are as follows: H0: No power in non-linear combinations - No misspecification, H1: The non-linear combinations have power-Misspecification.

\section{LM Test for Serial Correlation}

Breusch-Godfrey test (Godfrey 1978) is applied to test the serial correlation. Mathematically the following should hold true; Covariance $\left(\varepsilon_{\mathrm{i}}, \varepsilon_{\mathrm{j}}\right)=0, \forall \mathrm{i}$, j otherwise the series has a serial correlation. Serial correlation does not affect the unbiasedness of the regression estimators but rather affect the efficiency i.e. the estimators are not BLUE (Brooks 2014). The test has the following general null hypothesis and alternative hypothesis: $\mathrm{H}_{0}: p=0$, No serial correlation in the model, $\mathrm{H}_{1}: \mathrm{p} \neq 0$, There is serial correlation in the model.

\section{Test for Heteroscedasticity}

Test that all residuals have a constant variance. In the regular OLS estimation as well as for the ARDL model it is assumed that the residuals have a constant variance (homoscedasticity). If the model does not have a constant variance (heteroscedasticity) in the residuals the estimated coefficients will no longer be BLUE and will not have the minimum variance of the unbiased estimators. For the test of heteroscedasticity this study will use the Breusch-Pagan test for heteroscedasticity which has the following very general null and alternative hypothesis: $\mathrm{H}_{0}$ : Constant variance of the residuals Homoscedasticity,

$\mathrm{H}_{0}$ : Non-constant variance of the residuals - Heteroscedasticity.

Decision: If the probability of observed R-square is higher than a probability at five percent level of significance then the null hypothesis is accepted (it means there is homoscedasticity) and if the probability value of observed R-square is lower than a 
probability at five percent level of significance then the null hypothesis is rejected (it means there is heteroscedasticity).

\section{Test for Normality of the Residuals}

In order to test the Normality of the Residuals, the Jarque-Bera test is applied. The assumption that the residuals are normally distributed is necessary in order to conduct hypothesis tests of model parameters. Thus, non-normality may cause problems regarding statistical inference of the coefficient estimates such as significance tests and for confidence intervals that rely on the normality assumption (Brooks, 2014). The very general null and alternative hypotheses are as follows: H0: There is normality in the residuals, H1: There is non-normality in the residuals.

If the computed p-value of the JB statistic is sufficiently low or below five percent level of significance then the null hypothesis is rejected. On the other hand, if the p-value is reasonably high, the null hypothesis is accepted.

\section{Test for Stability}

To assess the stability of the long-run and short-run coefficients CUSUM and CUSUMSQ tests proposed by Brown et al. (1975) can be used. If there is instability in the coefficients one may increase the sample size or introduce dummy variables (Naiya \& Manap 2013; Juselius 2006; Fuinhas \& Marques 2012). The tests are based on the cumulative sum of the recursive residuals (CUSUM) and the cumulative sum of squared recursive residuals (CUSUMSQ) and are of a graphical nature whereby the residuals are updated recursively and are plotted against the breakpoints for the 5\% significance line. The cumulative sum of recursive residuals is plotted against the upper and lower $95 \%$ confidence bounds. The concept remains the same for CUSUMSQ. The long-run and short-run coefficients are stable if the plot of CUSUMSQ and CUSUM stay within the $5 \%$ significance level. In detail, both tests analyze if the residuals do not significantly deviate from its mean value by imposing parallel critical lines on a $5 \%$ significance level.

\section{RESULTS AND DISCUSSIONS}

\section{ADF Unit Root Test Results}

The time series properties of the variables were explored to determine the order of integration of each variable in the model. The stationary test was performed to avoid spurious regression problems normally associated with time series econometric modeling. Before applying ARDL, the order of integration is examined using the Augmented Dickey-Fuller (ADF) test. To conclude that whether to include trend or 
not, the time series plot in Figure 4.1, 4.2, 4.3, 4.4, 4.5, and 4.6 shows that lnRGDP, $\operatorname{lnGFCF}, \operatorname{lnHC}, \operatorname{lnGE}, \ln \mathrm{AID}$, and $\operatorname{lnTO}$ are trended variables. So, a trend is included in the ADF test for them along with intercept. The unit root test on the annual series of $\operatorname{lnRGDP}, \operatorname{lnGFCF}, \operatorname{lnHC}, \operatorname{lnGE}, \ln \mathrm{AID}$ and $\ln \mathrm{TO}$ at level data and first difference including both trend and intercept was carried out using ADF test as discussed in section 3.9.1. The unit root test results are presented in Table 4.9.

The ADF unit root test result indicates that none of the six variables of the model are integrated of order two; I(2). Thus the variables are integrated of order zero; I(0) and one; I(1). As can be seen from the Table the logged series of RGDP, GFCF, H, GE and $\mathrm{TO}$ are non-stationary in level form but taking first difference of the series makes them stationary, whereas the variable FA is stationary in log-level form.

Table 4.1: ADF Unit Root Test Results

\begin{tabular}{|l|l|l|l|l|l|l|}
\hline Variables & ADF test & P- value & \multicolumn{3}{l|}{ Critical Values } & \multirow{2}{*}{ Remarks } \\
\cline { 4 - 6 } & statistics & & At $1 \%$ & At $5 \%$ & At $10 \%$ & \\
\hline $\ln$ RGDP & -2.095 & 0.523 & -4.198 & -3.523 & -3.192 & \\
\hline$\Delta \ln$ RGDP & -5.914 & 0.0001 & -4.205 & -3.526 & -3.194 & $\mathrm{I}(1)$ \\
\hline $\ln$ GFCF & -2.875 & 0.1806 & -4.198 & -3.523 & -3.192 & \\
\hline$\Delta \ln$ GFCF & -5.318 & 0.0005 & -4.205 & -3.526 & -3.194 & $\mathrm{I}(1)$ \\
\hline $\ln \mathrm{HC}$ & -3.379 & 0.0682 & -4.198 & -3.523 & -3.192 & \\
\hline$\Delta \ln \mathrm{HC}$ & -6.606 & 0.0000 & -4.205 & -3.526 & -3.194 & $\mathrm{I}(1)$ \\
\hline $\ln \mathrm{GE}$ & -2.555 & 0.3014 & -4.198 & -3.523 & -3.192 & \\
\hline$\Delta \ln \mathrm{GE}$ & -4.896 & 0.0016 & -4.205 & -3.526 & -3.194 & $\mathrm{I}(1)$ \\
\hline $\ln \mathrm{AID}$ & -4.017 & 0.0033 & -4.198 & -3.523 & -3.192 & $\mathrm{I}(0)$ \\
\hline$\Delta \ln \mathrm{AID}$ & -6.161 & 0.0000 & -4.205 & -3.526 & -3.194 & \\
\hline $\ln \mathrm{TO}$ & -1.498 & 0.8143 & -4.198 & -3.523 & -3.192 & \\
\hline$\Delta \ln \mathrm{TO}$ & -6.240 & 0.0000 & -4.205 & -3.526 & -3.194 & $\mathrm{I}(1)$ \\
\hline
\end{tabular}

Based on the orders of integration obtained from the table above ARDL approach has been used instead of Engel Granger and Johansen approach since it is a pre-requisite for both of them that all the variables used in this analysis be integrated of the same order. And as is required by the ARDL model, the dependent variable is non-stationary i.e. it is integrated of order 1 . 


\section{ARDL Cointegration Test Results}

\section{a) Lag Length Selection}

The study made use of the Akaike Information criterion (AIC) to choose the optimal lag length. The decision was based on the result from the HQIC, AIC and FPE. Table 4.10 presents the result of the maximum number of lags which is given by AIC, HQIC and FPE.

Table.4.2: Optimal Lag Length Results

\begin{tabular}{|c|c|c|c|c|c|c|}
\hline Lag & LogL & LR & FPE & AIC & SC & HQ \\
\hline 0 & 77.92276 & NA & 0.001468 & -3.688347 & -3.432414 & -3.596520 \\
\hline 1 & 91.30930 & $21.96766^{*}$ & 0.000779 & -4.323554 & $-4.024966^{*}$ & -4.216423 \\
\hline 2 & 92.71674 & 2.237467 & $0.000764^{*}$ & $-4.344448^{*}$ & -4.003205 & $-4.222013^{*}$ \\
\hline 3 & 92.72892 & 0.018728 & 0.000806 & -4.293791 & -3.909892 & -4.156051 \\
\hline
\end{tabular}

Source: Authors Computation.

\section{b) Bound Test Results}

In order to achieve the objective of the study; to examine empirically the long and short run relationship among selected macroeconomic variables on the economic growth of Nepal, the co-integration relationship between RGDP and selected macroeconomic variables are tested using ARDL model. This study employed ARDL modeling for the formulation of long-run equilibrium between RGDP and selected variables. The bound test (F-statistics) has been applied to explain the existence of the co-integration relationship among variables in the model. The result of the ARDL bound test approach to cointegration is shown in Table 4.11. The optimal lag order of the ARDL model is set to Two (2) which is based on the Akaike information criterion. The adjusted sample is 1976-2016.

The empirical results in Table 4.11 refer to a long run relationship between NGDP and rest variables of the model because F-statistic for the Bounds Test is 5.69, it clearly exceeds even the $1 \%$ critical value for the upper bound. So, this study rejects the hypothesis of "No Long-Run Relationship", and accepts the alternative hypothesis that there is a Long-Run co-integration Relationship. 
Table 4.3: ARDL Bound Test for Cointegration

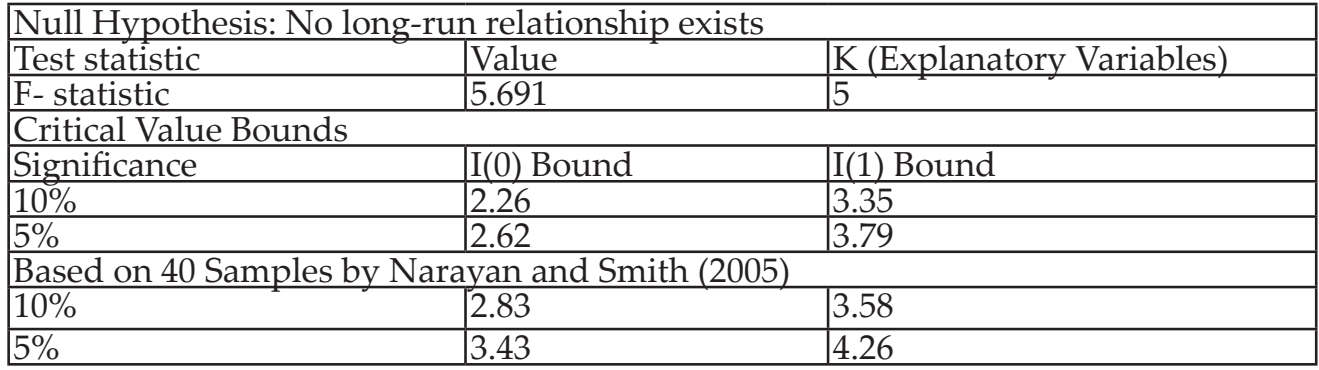

Source: Authors Computation.

\section{Long Run Coefficient Test Results}

After establishing a co-integration relationship between the series, Autoregressive Distribution Lag (ARDL) model can be established to determine long run and short run relationships. The estimated long run coefficients are shown in Table 4.12. The, empirical results in Table 4.12 refer that in line with the economic theories and previous empirical studies, the impact of GFCF on economic growth (RGDP) is positive and statistically significant at $1 \%$ level of significance. Since the coefficient of GFCF is positive, it means that it has a direct relationship with economic growth in the long run. This implies that a change in GFCF has the potential of spurring economic growth in Nepal. The coefficient of GFCF is 0.623 which implies that all else being equal, a one percentage point increase in GFCF leads to an increase in the per worker real gross domestic product by about 0.623 percentage point. This result supports the fact that increasing investment size enhances productivity which has a spillover effect on economic performance. This finding is in line with a study done by Afzal et al. (2010), Antwi, Mills and Zhao (2013), Mbulawa (2015), Ismaila and Imoughele (2015) and Biswas and Saha (2014) whereas, this finding is contrast with the findings of Sallam (2016).

Table 4.4: Estimated Long Run Coefficient Using the ARDL Approach

\begin{tabular}{|c|c|c|c|c|}
\hline \multicolumn{5}{|c|}{ ARDL $(1,0,1,0,1,1)$ Selected Based on AIC } \\
\hline \multicolumn{5}{|c|}{ Long Run Coefficients } \\
\hline Variables & Coefficient & Std. Error & t-Statistic & Prob \\
\hline $\ln G F C F$ & 0.623 & 0.144 & 4.338 & 0.0001 \\
\hline $\operatorname{lnHC}$ & -0.025 & 0.109 & -0.231 & 0.818 \\
\hline $\ln G E$ & 0.177 & 0.101 & 1.766 & 0.087 \\
\hline $\ln \mathrm{AID}$ & 0.068 & 0.086 & 0.791 & 0.435 \\
\hline $\operatorname{lnTO}$ & -0.129 & 0.063 & -2.024 & 0.050 \\
\hline C & 1.719 & 1.486 & 1.156 & 0.256 \\
\hline
\end{tabular}

Source: Authors Computation. 
Human Capital in the form of secondary school enrollment has a negative and highly insignificant relationship with economic growth in long run suggesting that its contribution to economic output is low as a result of the lack of quality education, lack of technology-based education, lack of incentives for improved student performance, frequent labor strikes and labor unrest. This finding is similar to the findings of Ullah and Rauf (2013) and Pritchett (2001) but dissimilar to the theory of Mankiw, Romer, and Weil (1992) and to the findings of Antwi, Mills and Zhao (2013).

Government Expenditure appears to be an important determinant of economic growth. The result shows that the relationship between per worker RGDP and GE is positive and statistically significant at $10 \%$ significance level in long run, this result agrees with the economic theory of Keynesian hypothesis. The coefficient of GE is 0.177 which implies that all else being equal, a one percentage point increase in GE leads to an increase in the per worker real gross domestic product by about 0.177 percentage point. This implies that an increase change of GE spurs economic growth in Nepal. This finding is in line with the standard theories and economic expectation because of the higher government expenditure on a productive venture the greater economic output, ceteris paribus. This finding is similar to the result of Ismaila and Imoughele (2015) and Gregorious and Ghosh (2007) but dissimilar to the findings of Antwi, Mills, and Zhao (2013) and Hafeez and Taha (2015).

On the other hand, in contrast to the previous findings, the finding of this study reveals a negative and statistically significant (at $5 \%$ ) relationship of openness to foreign trade with output growth. The coefficient of TO is -0.128 which implies that all else being equal, a one percentage point increase in TO leads to a fall in per worker real gross domestic product by about 0.128 percentage point. This suggests that the development of Nepal's international trade system has an adverse impact on the national economic performance. This may be because of lack of competitiveness in the global market with the production of standard and quality products and also due to human capital constraints and their inability to take advantage of international technology transfer. This finding is similar to the findings of Vlastou (2010), Zahonogo (2017) but dissimilar to the findings of Ismaila and Imoughele (2015) and Keho (2017).

The coefficient of Foreign Aid (AID) is positive and statistically insignificant. The positive and insignificant relationship implies that foreign aid in Nepal has not been productively used in projects and developmental issues. This could be due to a 'bad policy' environment as pointed out by Burnside-Dollar (2000) and Boone (1996). Kosack and Tobin (2006) concluded that aid works against development in a country with an extremely low level of human capital, and these countries have a very low 
human development index. This finding is similar to the result of Antwi, Mills, and Zhao (2013) and Mallik (2008).

\section{Short-run Dynamics Results of ADRL Process}

The ECM investigates the short-run dynamics and long-run effects of variables. The negative and significance error correction coefficient further provides the strong evidence that the variables are co-integrated. Thus the result of the error correction representation of the second step of the second stage of the ARDL method to cointegration is given in Table 4.13 .

Table.4.5: ECM Representation for the Selected ARDL Model

\begin{tabular}{|l|l|l|l|l|}
\hline ARDL $(1,0,1,0,1,1)$ & Model Based on AIC & \\
\hline Variables & Coefficient & Std. Error & t- Statistic & Prob. \\
\hline$\Delta \ln$ GFCF & 0.292 & 0.065 & 4.454 & 0.0001 \\
\hline$\Delta \ln H C$ & 0.224 & 0.056 & 3.990 & 0.0004 \\
\hline$\Delta \ln$ GE & 0.083 & 0.050 & 1.644 & 0.1102 \\
\hline$\Delta \ln$ AID & -0.024 & 0.037 & -0.647 & 0.5218 \\
\hline$\Delta \ln$ TO & 0.202 & 0.058 & 3.429 & 0.0017 \\
\hline ECT(-1) & -0.468 & 0.059 & -7.864 & 0.0000 \\
\hline R-Squared: 0.77 & Adjusted R-Squared: 0.75 & DW Stat: 2.10 \\
\hline
\end{tabular}

Source: Authors Computation.

The Table 4.13 depicts that there is a short run association between real gross domestic product (lnRGDP) and selected macro variables. The negative and statistically significant coefficient of the one period lagged error correction term $\left(\mathrm{ECM}_{\mathrm{t}-1}\right)$ provides further support to the existence of co-integration of the dependent variable real gross domestic product (lnRGDP) with its regressors included in the estimates. The size of $\left(\mathrm{ECM}_{\mathrm{t}-1}\right)$ is -0.468 which suggests that about 46 percent of the disequilibrium caused by previous period's shocks in the system converges back to the long run equilibrium. That is the short run deviation is corrected by $46 \%$ each period and it takes about two periods to return back to the long run equilibrium $(0.46+0.46=0.92$, about $100 \%$ deviation corrected). The positive and statistically significant short run coefficients related to $\operatorname{lnGFCF}, \operatorname{lnHC}$, and $\ln \mathrm{TO}$ indicate their respective importance in affecting the real gross domestic product (lnRGDP) in the short run. This suggests that the short run dynamic effect of the selected regressors on the real gross domestic product (lnRGDP) is positive.

$\mathrm{R}^{2}$, the coefficient of determination, defines the proportion of total variations in the dependent variable. In the above ECM model, the given value of $\mathrm{R}^{2}$ is 0.77 explaining 
$77 \%$ goodness of fit it means the model properly explains the RGDP. Similarly, the value of adjusted $R^{2}=0.75$ explains $75 \%$ goodness of fit which means $75 \%$ of total variation in dependent variable is explained by regression line and the rest $25 \%$ is due to the other factor.

The estimated coefficient of GFCF is positive and significant at one percent level. The statistically significant coefficient of GFCF at $1 \%$ level of significance $(p=0.0001<0.01)$ is of the size of 0.291 which indicate that all else being equal, a one percentage point increase in GFCF assists real GDP to increase by about 0.291 percentage point in the short run. This implies that there is a statistically significant short-run positive impact of GFCF on the economic growth in Nepal. Thus, the positive and significant effect of physical capital on economic growth is supported by both long run and short run dynamic models.

The estimated short-run coefficient of human capital is positive (0.224) and significant at one percent level of significance $(0.0004<0.01)$. This positive coefficient of human capital indicates that all else being equal, a one percentage point increase in Human Capital would lead to an increase in per worker real GDP by about 0.224 percentage point. This finding is similar to the result of Afzal et al (2010) and Antwi, Mills, and Zhao (2013).

A positive and insignificant relationship between government expenditure and economic growth is found in the short run suggesting that its contribution to output growth is low in the short run. On the other hand, the estimated short-run coefficient of foreign aid is negative and statistically insignificant suggesting that its contribution to output growth is low in the short run.

The estimated short-run coefficient of trade openness is positive (0.202) and statistically significant at one percent level of significance $(0.0017<0.01)$. This positive coefficient of trade openness implies that all else being equal, a one percentage point increase in trade openness leads to an increase in per worker real GDP by about 0.202 percentage point. This finding is similar to the findings of Keho (2017).

\section{Diagnostic Test Results}

The reliability of the estimated ARDL model is further investigated through its diagnostic test of Regression Specification Error Test, serial correlation test, heteroscedasticity test, normality test and stability test. The results are given in Table 4.14, Table 4.15, Table 4.16, Table 4.17, Figure 4.7, Figure 4.8, and Figure 4.9. 


\section{Regression Specification Error Test Result}

Ramsey RESET Test is used to check whether the specified functional form is correct or not. The details result is given in Table 4.14. Table 4.14 shows that the probability value of F-statistics and t-statistics are like 0.1133 and $0.1133>0.05$, which exceeds $5 \%$ significance level. Therefore, this study accepts the null hypothesis of the correct functional form of the model. Thus, the Ramsey RESET for model specification indicates that the model has no evidence of any misspecification.

Table 4.6: RESET Test Result

\begin{tabular}{|l|c|c|c|c|}
\hline \multicolumn{4}{|l|}{ Omitted Variables: Squares of fitted values } & \\
\hline & Value & Df & Probability & \\
\hline t-statistic & 1.631027 & 30 & 0.1133 & \\
\hline F-statistic & 2.660248 & $(1,30)$ & 0.1133 & \\
\hline
\end{tabular}

\section{Serial Correlation LM Test Result}

Serial correlation test measures the serial correlation of residuals. It is assumed that the error terms in the regression equation are uncorrelated with one another. This phenomenon is called serial correlation. The result of the serial correlation is given in details in Table 4.15 .

Table 4.7: Serial Correlation Test Result

\begin{tabular}{|l|r|l|r|}
\hline Breusch-Godfrey Serial Correlation LM Test: & \\
\hline F-statistic & 0.336578 & Prob. F(2,29) & 0.7170 \\
\hline Obs*R-squared & 0.930114 & Prob. Chi-Square (2) & 0.6281 \\
\hline
\end{tabular}

Table 4.15, shows that the probability value of F-statistics and observed R-squared are like 0.7170 and $0.6281>0.05$, which clearly exceeds $5 \%$ significance level, this means the acceptance of null hypothesis i.e. there is no serial correlation in residuals or residuals are not serially correlated. Thus, this result fulfills the assumption of no serial correlation of error terms in the ordinary least square method.

\section{Heteroscedasticity Test Result}

In the regular OLS estimation as well as for the ARDL model it is assumed that the residuals have a constant variance (homoscedasticity). This test measures the nature of existence of variance of residual over the period of time. It is one of the statistical assumptions of time series data and ordinary least squares that the error terms for all observation have a common variance or constant variance. The detail result is shown in Table 4.16. 
Table 4.7: Heteroscedasticity Test Result

\begin{tabular}{|l|r|l|r|}
\hline Heteroskedasticity Test: Breusch-Pagan-Godfrey \\
\hline F-statistic & 0.515195 & Prob. F(9,31) & 0.8522 \\
\hline Obs*R-squared & 5.334574 & Prob. Chi-Square (9) & 0.8042 \\
\hline Scaled explained SS & 2.673851 & Prob. Chi-Square (9) & 0.9758 \\
\hline
\end{tabular}

Table 4.16 shows that the probability value of F-statistics and observed R-squared are 0.8522 and 0.8042 respectively which clearly exceeds $5 \%$ significance level, this means the acceptance of the null hypothesis i.e. no heteroscedasticity in residuals. This means there is homoscedasticity.

\section{Normality Test Result}

Histogram normality test shows the distribution of residuals. It observes the normal distribution of error terms. Ordinary least square and time series data assumes the normal distribution of residuals error terms. The details result is given in the Table 4.17 .

For Normality test basically the Jarque-Bera statistics is observed in order to conform whether the residuals are normally distributed or not. In the Table 4.17, the Jarque Bera statistics is 0.1357 with its probability value 0.9343 which clearly exceeds $5 \%$ significance level. It indicates acceptance of the null hypothesis i.e. the residuals are normally distributed.

Table 4.8: Statistics of Normality Test Result

\begin{tabular}{|l|l|}
\hline Statistical Tools & Statistical Value \\
\hline Mean & $-2.35 \mathrm{e}-16$ \\
\hline Median & 0.00019 \\
\hline Maximum & 0.0408 \\
\hline Minimum & -0.0417 \\
\hline Std. Dev & 0.0194 \\
\hline Skewness & -0.0684 \\
\hline Kurtosis & 2.7535 \\
\hline Jarque-Bera & 0.1357 \\
\hline Probability & 0.9343 \\
\hline
\end{tabular}


Fig.4.7: Histogram Normality Test Results

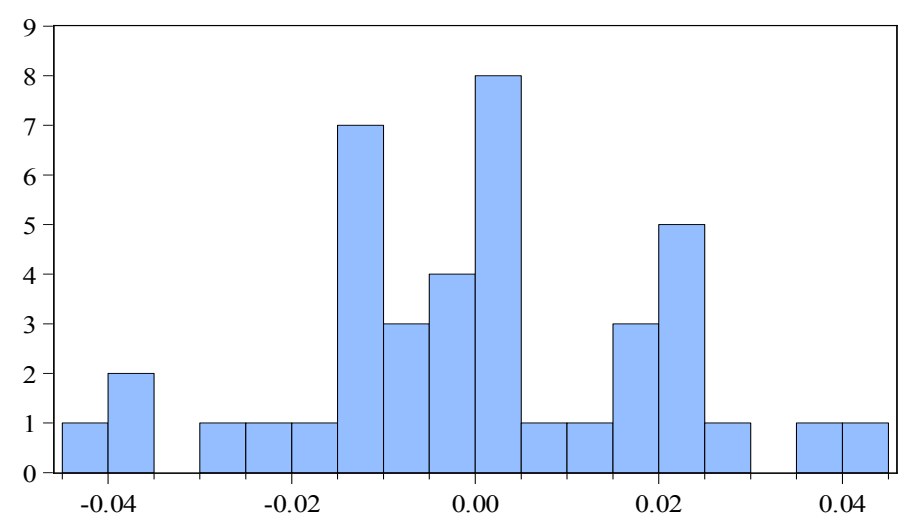

Stability Test Results

Stability of the long-run coefficients together with the short-run dynamics, the cumulative sum (CUSUM) and the cumulative sum of squares (CUSUM) are applied. The stability of the estimated coefficients of the error correction model and a graphical representation of CUSUM and CUSUMQ statistics are shown in Figure 4.8 and 4.9. According to Bahmani-Oskooee, (2004) the null hypothesis cannot be rejected if the plot of these statistics remains within the critical bound on the $5 \%$ significance level.

As it is clear from Figure 4.8 and 4.9, the plots of both the CUSUM and the CUSUMQ are within the boundaries and hence providing evidence that these statistics confirm the stability of model i.e. the model do not suffer from any structural instability over the period of the study.

Fig.4.8: Plot of Cumulative Sum of Recursive Residuals

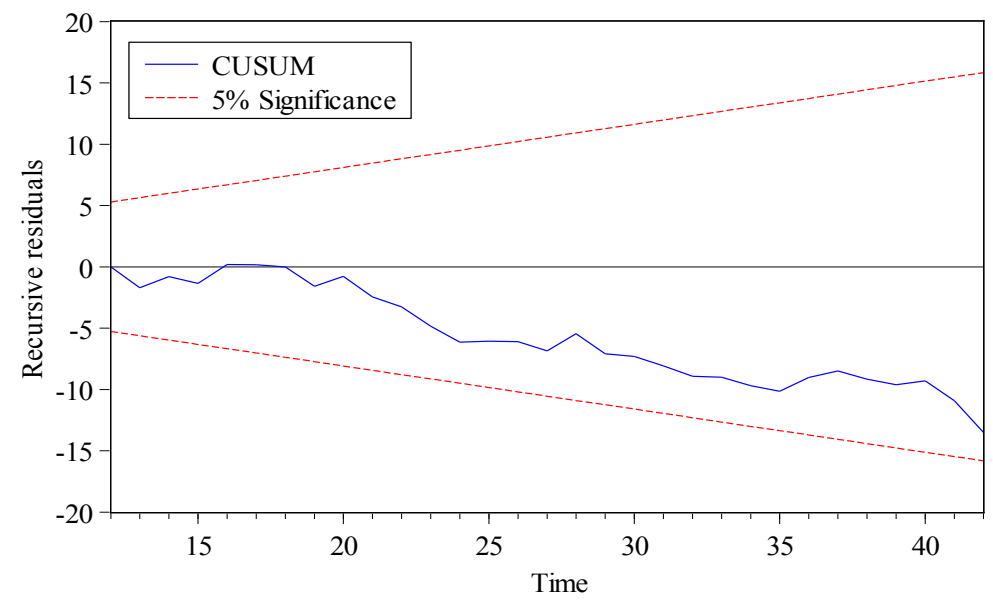


Fig.4.9: Plot of Cumulative Sum of Square of Recursive Residuals

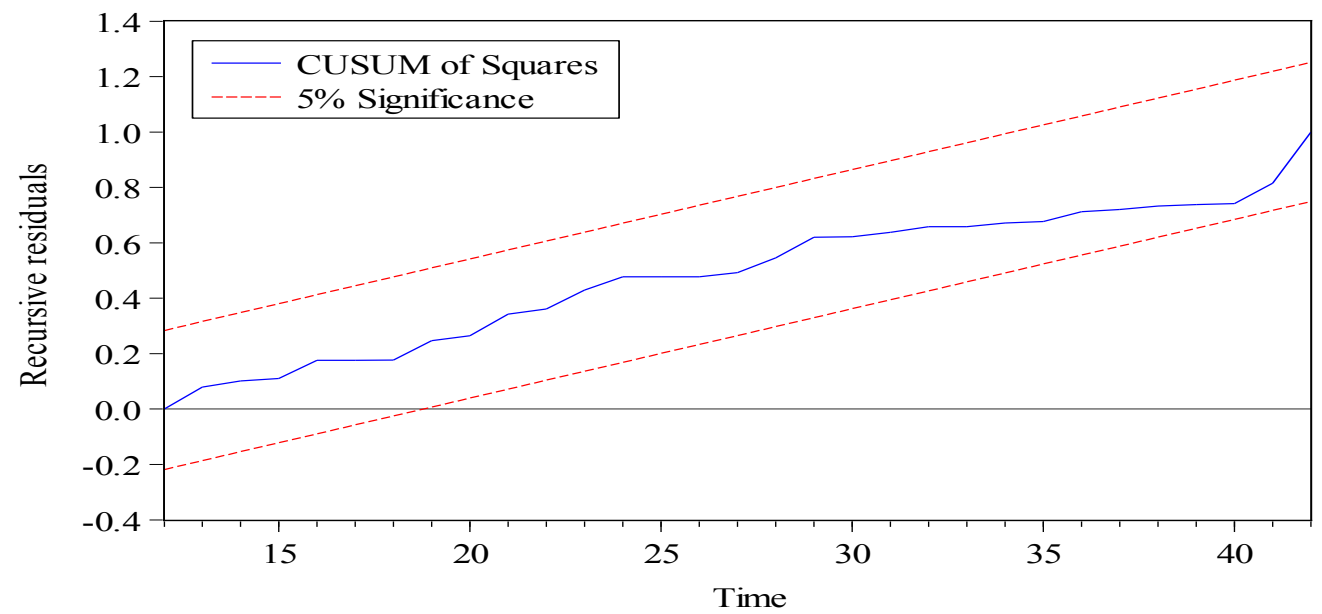

The pinpoint of above Diagnostic Test is that this model does not suffer from any problems of incorrect functional form, serial correlation, heteroscedasticity, nonnormal distribution and instability of the model. Since ordinary least square and time series models are based on the assumptions of Stationarity, Normality, Linearity, No serial correlation, Homoscedasticity, No multicollinearity. Therefore, the obtained results are robust due to satisfying the above assumptions and thus this model is BLUE.

In conclusion, the ARDL result shows that the alternative hypothesis of the existence of a significant relationship between selected macroeconomic variables (physical capital, human capital, government expenditure, foreign aid and openness to foreign trade) and economic growth has been accepted. This means rejection of the null hypothesis of no significant relationship between selected macroeconomic variables and economic growth.

\section{CONCLUSIONS}

This study based on ARDL and ECM concluded that there exists a long-run relationship between GFCF, human capital, government expenditure, foreign aid, trade openness and economic growth in Nepal. The general objective of this research was to analyze the macro determinants of economic growth in Nepal. Based on the statistical evidence, this paper has demonstrated that gross fixed capital formation and government expenditure are the key macro determinants of Nepalese economy. The ARDL bound test approach reveals the presence of a co-integrating relationship between gross fixed capital formation (lnGFCF) and government expenditure (lnGE) in escalating the level 
of output in Nepal's economy in the long-run, as measured using real Gross Domestic Product (lnRGDP). In contrast, the ARDL bound test approach reveals the presence of a cointegrating relationship between trade openness (lnTO) and human capital (lnHC) in retarding the level of output in Nepal's economy.

The growth trend of the employed variables showed that they are fluctuating over the period of the study being affected by the formulation and execution of various acts and policies by the government of Nepal. The results of ARDL approach to cointegration showed that Gross Fixed Capital Formation have positive and significant relationship with real gross domestic product both in the long run and short run, Government Expenditure has significant positive relationship with real GDP in the long run and their relationship is positive and insignificant in the short run, trade openness has a negative and significant relationship with the real GDP in long run while their relationship is found to be positive and statistically significant in short run. Human Capital has negative and insignificant relationship with real gross domestic product in long run but has significant positive impact on real GDP in short run. Similarly, foreign aid has an insignificant positive relationship with real GDP in the long run while the relationship is negative and insignificant in the short run.

In general, the empirical results revealed that there exists a positive long-run relationship between gross fixed capital formation, government expenditure and economic growth and a negative long-run relationship between trade openness and economic growth. This confirms the interdependence between economic growth and selected macroeconomic variables.

According to the obtained results, there are some policy implications which need to be put into consideration. In order to achieve the desired rate of economic growth the following policies are suggested. GFCF a proxy for Physical Capital was found to have a positive impact on economic growth. It is suggested that there should be a continuous investment in gross fixed capital formation including plants, machinery, raw materials, industrial buildings, road network, technology (research and development) and other capital stock that are central to production and other economic activities in the economy. As education_centric human capital is found to have a negative impact on economic growth, it is recommended that structural changes should be make in school institutions with the provision of providing quality education with cognitive skills and added resources through quality and skilled teachers. There is a need to put stringent policy in place to minimized strike in Nepalese labor sector in order to enhance their performance to the Nepalese economy. Government must focus on promoting more competition, so that parental demand will create strong incentives to individual schools; autonomy in local decision making, so that individual schools and 
their leaders will take actions to promote student achievement; and, an accountability system that identifies good school performance and leads to rewards.

Government expenditure stood as major macro determinants of Nepalese economy, therefore, the government has to increase its development expenditure to the long-term projects for a steady increase in the GDP and furthermore, budgetary classification should be done according to the priority and productivity nature of different sectors. Nepal must have more effective trade openness, particularly by productively controlling import of consumption goods or by adopting import substitution policies, in boosting their economic growth through international trade. Nepal should place relatively more emphasis on exports of products in conjunction with policies to encourage exports through increased production with the aim to boost domestic production. More initiatives should be instigated in attracting more foreign aid to this country and its productive use and allocation. Thus, it is suggested that the government of the country must take stronger steps to further enhance the macroeconomic variables in respect of higher economic growth by carrying out relevant policy reform to encourage investment, allow effective governance, and promote human capital accumulation.

Acknowledgement: Authors would like to gratefully acknowledge the valuable comments and suggestions on the paper offered by Prof. Dr. Madhav Prasad Dahal. The usual disclaimer applies.

\section{REFERENCES}

Afzal, M., Farooq, M. S., Ahmad, H. K., Begum, I., \& Quddus, M. A. (2010). Relationship between school education and economic growth in Pakistan: ARDL bound testing approach to cointegration. Pakistan Economic and Social Review, 48(1), 39-60. https://www.jstor.org/stable/41762413.

Akpan, N. (2005). Government expenditure and economic growth in Nigeria. CBN Economic and Financial Reviews, 43(1), 51-69.

Amjad, R. (2005). Skills and competitiveness: Can Pakistan break out of the low-level skills trap? The Pakistan Development Review, 44(4), 387-409. http://www.pide. org.pk/pdf/PDR/2005/Volume4/387-409.pdf.

Antwi, S., Mills, E. F. E. A., \& Zhao, X. (2013). Impact of macroeconomic factors on economic growth in Ghana: A cointegration analysis. International Journal of Academic Research in Accounting, Finance and Management Sciences, 3(1), 3545. http://www.hrmars.com/admin/pics/1410.pdf. 
Bacha, E. L. (1990). A Three-gap model of foreign transfers and the GDP growth rate in developing countries. Journal of Development Economics, 32(2), 279-296. https:// doi.org/10.1016/0304-3878(90)90039-E.

Bahamani-Oskooee, M., \& Ardalani, Z. (2006). Exchange rate sensitivity of U.S. trade flows: Evidence from industry data. Southern Economic Journal, 72(3), 542-559. https://www.jstor.org/stable/20111832.

Banerjee, A., Dolado, J. J., Galbraith, J. W., \& Hendry, D. (1993). Cointegration, error correction and the econometric analysis of Non-stationary data. Oxford: Oxford University Press.

Banerjee, A., Dolado, J., \& Mestre, R. (1998). Error-correction mechanism tests for cointegration in a single-equation framework. Journal of Time Series Analysis, 19(3), 267-283. https://doi.org/101111/1467-9892.00091.

Barro, R. J. (1990). Government spending in a simple model of endogenous growth. Journal of Political Economy, 98(5), 103-125. https://doi.org/10.1086/261726.

Barro, R. J. (1991). Economic growth in a cross section of countries. Quarterly Journal of Economics, 106(1), 407-443. https://doi.org/10.2307/2937943.

Barro, R. J. (1996). Determinants of economic growth: A cross-country empirical study. Cambridge MA: MIT Press. http://www.nber.org/papers/w5698.pdf.

Barro, R. J. (2003). Determinants of economic growth in a panel of countries. Annals of Economics and Finance, 4(2), 231-274. http://down.aefweb.net/WorkingPapers/ w505.pdf.

Barro, R. J., \& Sala-i-Martin, X. (1995). Economic growth. New York: McGraw-Hill. https://trove.nla.gov.au/work/2167156.

Barro, R. J., \& Sala-i-Martin, X. (1997). Technological diffusion, convergence, and growth. Journal of Economic Growth, 2(1), 1-26. https://doi.org/10.1023/ A:1009746629269.

Beddies, C. (Aug 1999). Investment, capital accumulation, and growth: Some evidence from Gambia: 1964-1998 (Working Paper: 99/117), International Monetary Fund.

Benhabib, J., \& Spiegel, M. M. (1994). The role of human capital in economic development: Evidence from aggregate cross-country data." Journal of Monetary Economics, 34(2), 143-174.

Biswas, S., \& Saha, A. K. (2014). Macroeconomic determinants of economic growth in India: A time series analysis. SOP Transaction on Economic Research, 1(2), 5472. 
Boone, P. (1996). Politics and the effectiveness of foreign aid. European Economic Review, 40, 289-329. http://dx.doi.org/10.1016/0014-2921(95)00127-1.

Brautigam, D. A., \& Knack, S. (2004). Foreign aid, institutions, and governance in Sub-Saharan Africa, Economic Development and Cultural Change, 52(2), 255-285. http://www.jstor.org/stable/10.1086/380592.

Brooks, C. (2014). Introductory econometrics for finance, (3 ${ }^{\text {rd }}$ ed.). New York: Cambridge university press.

Brown, R. L., Durbin, J., \& Evans, J. M. (1975). Techniques for testing the constancy of regression relations over time. Journal of the Royal Statistical Society, Series B, 37(2), 149-163. https://www.jstor.org/stable/2984889.

Burnside, C., \& Dollar, D. (2000). Aid, policies, and growth. American Economic Review, 90(4), 847-868.

Chatterji, M. (1998). Tertiary education and economic growth. Regional Studies, 32(4), 349-354. https://doi.org/10.1080/00343409850117807.

Chenery, H. B., \& Strout, A. M. (1966). Foreign assistance and economic development. American Economic Review, 56(4), 679-733. https://www.jstor.org/ stable/1813524.

Coe, D. T., \& Helpman, E. (1995). International R \& D spillovers. European Economic Review, 39, 859-887. https://doi.org/10.1016 /0014-2921(94)00100-E.

Dickey, D. A., \& Fuller, W. A. (1979). Distribution of the estimators for autoregressive time series with a unit root. Journal of the American Statistical Association, 74(366), 427-431. https://www.jstor.org/stable/2286348.

Domar, E. (1946). Capital expansion, rate of growth and employment. Econometrica, 14, 137-147. http://www.jstor.org/stable/1905364.

Edoumiekumo, S. G., \& Opukri, C. O. (2013). Economic growth factor in Nigeria: The role of global trade. American Journal of Humanities and Social Sciences, 1(2), 5155. https://doi.org/10.11634/232907811301303.

Engle, R. F., \& Granger, C. W. J. (1987). Cointegration and error correction: Representation, estimation, and testing. Econometrica, 55(2), 251-267. https:// www.jstor.org/stable/1913236.

Easterly, W., \& Rebelo, S. (1993). Fiscal policy and economic growth: An empirical investigation. Journal of Monetary Economics, 32(3), 417-458. https://doi. org/10.1016/0304-3932(93)90025-B.

Frankel, J. A., \& Romer, D. (1999). Does trade cause growth? American Economic Review, 89(3), 379-399. DOI: 10.1257/aer.89.3.379. 
Fuinhas, J. A., \& Marques, A. C. (2012). Energy consumption and economic growth nexus in Portugal, Italy, Greece, Spain and Turkey: An ARDL bounds test Approach (1965-2009). Energy Economics, 34(2), 511-517. DOI: 10.1016/j. eneco.2011.10.003.

Ghura, D. (Dec. 1997). Private investment and endogenous growth: Evidence from cameroon. (Working Paper: 97/165), International Monetary Fund.

Godfrey, L. G. (1978). Testing against general autoregressive and moving average error models when the regressors include lagged dependent variables. Econometrica: Journal of the Econometric Society, 46(6), 1293-1301. https://www. jstor.org/stable/1913829.

Granger, C. (1981). Some properties of time series data and their use in econometric model specification. Journal of Econometrics, 16(1), 121-130. https://doi. org/10.1016/0304-4076 (81)90079-8.

Gregorious, A., \& Ghosh, S. (2007). The impact of government expenditure on growth: empirical evidence from the heterogeneous panel. http://www.brunel.ac.uk/9379/ efwps/0701.pdf.

Grossman, G., Helpman, E. (1991a). Innovation and growth in the global economy. Cambridge, MA: The MIT Press.

Grossman, G. M., \& Helpman, E. (1991b). Trade, knowledge spillovers, and growth. European Economic Review, 35, 517-526. https://doi.org/10.1016/00142921(91)90153-A.

Gupta, K. L., \& Islamm, M. A. (1983). Foreign capital, savings and growth-An international cross-section study, Dordrecht: Reidel publishing company.

Hafeej, A., \& Taha, M. (2015). Impact of macroeconomic variables on economic growth: Evidence from Pakistan. AUG International Journal of Engineering and Technology, 1, 65-75. http://www.aguijet.com.

Harris, R., \& Sollis, R. (2003). Applied time series modelling and forecasting. West Sussex: Wiley.

Harrison, A., \& Hanson, G. (1999). Who gains from trade reform? Some remaining puzzles. Journal of Development Economics, 59(1), 125-154. http://dx.doi. org/10.1016/S0304-3878(99)00008-5.

Harrod, R. F. (1939). An essay in dynamic theory. Economic Journal, 49(193), 14-33. http://www.jstor.org/stable/2225181. 
Hasan, A., \& Nasir, Z. M. (2008). Macroeconomic factors and equity prices: An empirical investigation by using ARDL approach. The Pakistan Development Review. 47(4), 501-513. https://www.jstor.org/stable/41261237.

Hansen, H., \& Tarp, F. (2000). Aid effectiveness disputed. Journal of International Development, 12, 375-398. https://doi.org/10.1002/(SICI)1099.

Hoover, K., \& Perez, S. (2004). Truth and robustness in cross-country growth regression. Oxford Bulletin of Economics and Statistics, 76, 763-798. https://doi.org/10.1111/ j.1468-0084.2004.101_1.x.

Ismaila, M., \& Imoughele, L. M. (2015). Macroeconomic determinants of economic growth in Nigeria: A co-integration approach. International Journal of Academic Research in Economics and Management Sciences, 4(1), 34-46. http://dx.doi. org/10.6007/IJAREMS/v4-i1/1485.

Jensen, P. S., \& Paldam, M. (2003). Can the new aid-growth models be replicated? (Working Paper: 17), Institute for Economics: Aarhus.

Johansen, S. (1988). Statistical analysis of co-integration vectors. Journal of Economic Dynamics and Control, 12(2/3), 231-254. https://doi.org/10.1016/01651889(88)90041-3.

Johansen, S., \& Juselius, K. (1990). Maximum likelihood estimation and inference on cointegration-with the application to the demand for money. Oxford Bulletin of Economics and Statistics, 52(2), 169-210. http://dx.doi.org/10.1111/j.14680084.1990.mp52002003.x.

Juselius, K. (2006). The cointegrated VAR model: Methodology and applications. New York: Oxford University Press.

Kaldor, N. (1955). Alternative theories of distribution. The Review of Economic Studies, 23(2), 83-100. http://www.jstor.org/stable/2296292.

Karras, G. (2006). Foreign aid and long-run economic growth: Empirical evidence for a panel of developing countries. Journal of International Development, 18(7), 1528. DOI: $10.1002 /$ jid.1187.

Keho, Y. (2017). The impact of trade openness on economic growth: The case of cote d'Ivoire. Cogent Economics and Finance, 5(1), 1-14. https://doi.org/10.1080/2332 2039.2017.1332820.

Khan, I., Najir, M. I., Fareed, Z., Najir, M. R., \& Faryal. (2017). Impact of macroeconomic factors on development of Pakistan. International Journal of Accounting and Economics Studies, 5(1), 63-67. www.sciencepubco.com/index.php/IJAES. 
Korman, J., \& Bratimasrene, T. (2007). The relationship between government expenditure and economic growth in Thailand. Journal of Economic Education, 14, 234-246.

Kosack, S. \& Tobin, T. (2006). Funding self-sustaining development: The role of aid, FDI and government in economic success. International Organization. 60, 205243. http://dx.doi.org/10.1017/S0020818306060097.

Kremers, J. J. M., Ericsson, N. R., \& Dolado, J. J. (1992). The power of cointegration tests. Oxford Bulletin of Economics and Statistics, 54(3), 325-348. https://doi. org/10.1111/j.1468-0084.1992.

Levine, R., \& Renelt, D. (1992). A sensitivity analysis of cross-country growth regressions. The American Economic Review, 82(4), 942-963. https://www.jstor. org/stable/2117352.

Lucas, R. E. (1988). On the mechanics of economic development. Journal of Monetary Economics, 22(1), 3-42. https://doi.org/10.1016/0304-3932(88)90168-7.

Mallik, G. (2008). Foreign aid and economic growth: A cointegration analysis of the six poorest African countries. Economic Analysis and Policy, 38(2), 251-260. https:// doi.org/10.1016/S0313-5926(08)50020-8.

Mankiw, G. N., Romer, D., \& Weil, D. N. (1992). A contribution to the empirics of economic growth. Quarterly Journal of Economics, 107(2), 407-437. https://www. jstor.org/stable/2118477.

Mbulawa, S. (2015). Effect of macroeconomic variables on economic growth in Botswana. Journal of Economics and Sustainable Development, 6(4), 68-77.

Mosley, P. (1980). Aid, savings and growth revisited. Oxford Bulletin of Economics and Statistics, 42(2), 79-95. https://doi.org/10.1111/j.1468-0084.1980.mp42002002.x.

Naiya, I. I., \& Manap, T. A. A. (2013). Structural transformation, poverty and inequality in Nigeria: An ARDL bound testing technique. International Journal of Economics and Finance 5(4), 141. DOI: 10.5539/ijef.v5n4p141.

Narayan, P. K., \& Smyth, R. (2005). Electricity consumption, employment and real income in Australia, evidence from multivariate granger causality tests. Energy Policy, 33(9), 1109-1116. DOI: 10.1016/j.enpol.2003.11.010.

Newfarmer, R., \& Sztajerowska, M. (2012). Trade and Employment in a fast-changing World in D. Lippoldt (Ed.), Policy Priorities for International Trade and Jobs, Paris, OECD. Available at SSRN: https://ssrn.com/abstract=2127162. 
Odhiambo, N. M. (2009). Energy consumption and economic growth in Tanzania: An ARDL bounds testing approach. Energy Policy, 37(2), 617-622. http://hdl. handle.net/10500/7168.

Papanek, G. F. (1972). The effect of aid and other resource transfers on savings and growth in less developed countries. Economic Journal, 82(3), 935-950.

Pasinetti, L. L. (1962). Rate of profit and income distribution in relation to the rate of economic growth. Review of Economic Studies, 29(4), 167-279. http://hdl.handle. net/10.2307/2296303.

Pattichis, C. A. (1999). Price and income elasticities of disaggregated import demands: results from UECMS and an application. Applied Economics, 31, 1061-1071. https://doi.org/10.1080/000368499323544.

Peseran, M. H., \& Peseran, B. (1997). Working with Microfit 4.0. Interactive econometric Analysis. Oxford: Oxford University Press.

Pesaran, M. H., \& Shin, Y. (1999). An autoregressive distributed lag modelling approach to cointegration analysis in econometrics and economic theory in the 20th century: The Ragnar Frisch Centennial Symposium, Strom, S. (ed.) Cambridge University Press, 371-413.

Pesaran, M. H., Shin, Y., \& Smith, R. J. (2001). Bounds testing approaches to the analysis of level relationships. Journal of Applied Econometrics, 16(3), 289-326. https:// doi.org/10.17863/CAM.5093.

Phillips, P. C. B. \& Perron, P. (1988). Testing for a unit root in time series regression. Biometrika, 75(2), 335-346. https://www.jstor.org/stable/2336182.

Prebisch, R. (1962). The economic development of latin America and its principal problems. Economic Bulletin for Latin America, 7(1), 1-22. http://repositorio. cepal.org/handle/11362/29973.

Pritchett, L. (2001). Where has all education gone? The World Bank Economic Review, 15(3), 367-391. https://www.jstor.org/stable/3990107.

Rahman, H. U., \& Afzal, M. (2003). The J curve phenomenon: An evidence from Pakistan. Pakistan Economic and Social Review, 41(1/2), 45-58

Ramsey, J. B. (1969). Tests for specification errors in classical linear least-squares regression analysis. Journal of the Royal Statistical Society. Series B (Methodological), 31(2), 350-371. http://www.jstor.org/stable/2984219.

Rebelo, S. (1991). Long-run policy analysis and long-run growth. Journal of Political Economy, 99(3), 500-521. http://www.jstor.org/stable/2937740. 
Rivera-Batiz, L. A., \& Romer, P. M. (1991). International trade with endogenous technological change. European Economic Review, 35, 971-1001. https://doi. org/10.1016/0014-2921(91)90048-N.

Romer, P. M. (1986). Increasing returns and long-run growth. Journal of Political Economy, 95(5), 1002-1037. http://www.jstor.org/stable/1833190.

Romer, P. M. (1990). Endogenous technological change. Journal of Political Economy, 98, 71-102. https://doi.org/10.1086/261725.

Romer, P. M. (1994). New goods, old theory, and the welfare costs of trade restrictions. Journal of Development Economics, 43, 5-38. https://doi.org/10.1016/03043878(94)90021-3.

Sallam, M. A. M. (2016). Factors promoting economic growth in egypt: Evidence from ARDL approach. Journal of Business and Economics, 7(11), 1804-1814. http:// www.academicstar.us.

Sargan, J. D. (1984). Wages and prices in the U.K. in econometrics and quantitative economics. Oxford: Blackwell.

Sezgin, S., \& Yildirim, T. (2002). The demand for Turkish defense expenditure. Defence and Peace Economics, 13(2), 121-128. https://doi.org/10.1080/10242690210973.

Shim, J. K. \& Siegel, J. G. (1995). Dictionary of economics. New York: John Wiley and Sons.

Singer, H.W. (1950). The distribution of gains from trade between investing and borrowing countries. American Economic Review, 40(2), 473-485. http://www. jstor.org/stable/1818065.

Srestha, U. (2008). Macroeconomic variables and its impact on economic development of Nepal. (unpublished Master's Thesis), Tribhuvan University, Nepal.

Solow, R. (1956). A contribution to the theory of economic growth. Quarterly Journal of Economics, 50, 65-94. http://www.jstor.org/stable/1884513.

Suliman, M., \& Osman, O. A. (1994). War in Darfur: The desert versus the Oasis syndrome. London, UK: Institute for African Alternatives.

Swan, T. W. (1956). Economic growth and capital accumulation. The Economic Record, 32(2), 334-361. https://doi.org/10.1111/j.1475-4932.1956.tb00434.

Tanninen, H. (1999). Income inequality, government expenditures and growth. Applied Economics, 31(9), 1109-1117. DOI: 10.1080/000368499323599.

Tian, G. G., \& Ma, S. (2010). The relationship between stock returns and the foreign exchange rate: The ARDL approach. Journal of the Asia Pacific Economy, 15(4), 490-508. http://ro.uow.edu.au/commpapers/3064. 
Tilak, Jandhyala B. G. (1994). Education for development in Asia. New Delhi: Sage Publications.

Tzougas J. (2013). Immigration, economic growth and unemployment in Greece: An application of the ARDL bounds testing approach to cointegration. https://ssrn. com/abstract $=2297466$.

Ullah, F., \& Rauf, A. (2013). Impacts of macroeconomic variables on economic growth: A panel data analysis of selected Asian countries. International Journal of Information, Business, and Management, 5(2), 4-12.

Verma, R. (2007). Savings, investment and growth in India: An application of the ARDL bounds testing approach. South Asia Economic Journal, 8(1), 87-98. http:// ro.uow.edu.au/commpapers/453.

Vlastou, I. (2010). Forcing Africa to open up to trade: Is it worth it? The Journal of Developing Areas, 44(1), 25-39. https://www.jstor.org/stable/41428192.

Zahonogo, P. (2017). Trade and economic growth in developing countries: Evidence from Sub-Saharan Africa. Journal of African Trade, 3, 41-56. https://doi. org/10.1016/j.joat.2017.02.001. 